Review

\title{
Climbing fibers in spinocerebellar ataxia: A mechanism for the loss of motor control
}

\author{
C.J.L.M. Smeets, D.S. Verbeek * \\ Department of Genetics, University of Groningen, University Medical Center Groningen, Groningen, The Netherlands
}

\section{A R T I C L E I N F O}

\section{Article history:}

Received 18 August 2015

Revised 19 November 2015

Accepted 9 January 2016

Available online 12 January 2016

\section{Keywords:}

Spinocerebellar ataxia

Climbing fibers

Synaptic plasticity

Glutamate

Common pathology

Mouse models

\begin{abstract}
A B S T R A C T
The spinocerebellar ataxias (SCAs) form an ever-growing group of neurodegenerative disorders causing dysfunction of the cerebellum and loss of motor control in patients. Currently, 41 different genetic causes have been identified, with each mutation affecting a different gene. Interestingly, these diverse genetic causes all disrupt cerebellar function and produce similar symptoms in patients. In order to understand the disease better, and define possible therapeutic targets for multiple SCAs, the field has been searching for common ground among the SCAs. In this review, we discuss the physiology of climbing fibers and the possibility that climbing fiber dysfunction is a point of convergence for at least a subset of SCAs.
\end{abstract}

(c) 2016 Elsevier Inc. All rights reserved.

\section{Contents}

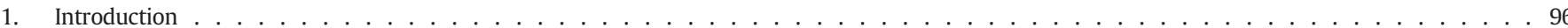

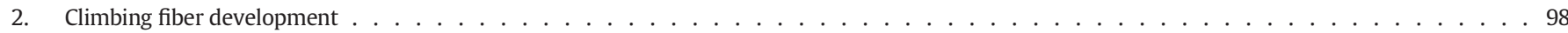

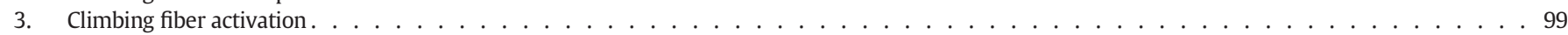

4. Synaptic plasticity and climbing fiber control. . . . . . . . . . . . . . . . . . . . . . . . . . . . . . 999

4.1. Postsynaptic parallel fiber long-term depression . . . . . . . . . . . . . . . . . . . . . . . . . . . . . . . . 100

4.2. Postsynaptic parallel fiber long-term potentiation . . . . . . . . . . . . . . . . . . . . . . . . . . 100

4.3. Presynaptic parallel fiber long-term depression . . . . . . . . . . . . . . . . . . . . . . . . . . . . . 100

4.4. Presynaptic parallel fiber long-term potentiation . . . . . . . . . . . . . . . . . . . . . . 100

4.5. Postsynaptic climbing fiber long-term depression . . . . . . . . . . . . . . . . . . . . . . . . . . . . . 101

4.6. The climbing fiber as control switch . . . . . . . . . . . . . . . . . . . . . . . . . . . . . . . . . . 101

5. The importance of glutamate and calcium in synaptic plasticity . . . . . . . . . . . . . . . . . . . . . . . . . . . . . . . . . 101

6. Climbing fiber deficits and glutamate dysregulation in mouse models of spinocerebellar ataxia . . . . . . . . . . . . . . . . . . . . . . . . . 101

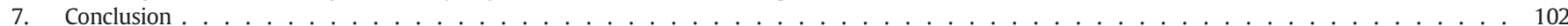

Acknowledgments . . . . . . . . . . . . . . . . . . . . . . . . . . . . . . . . . . . . . . . 103

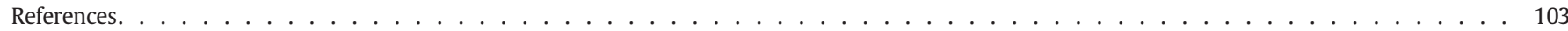

Abbreviations: AMPA, $\alpha$-amino-3-hydroxy-5-methylisoxazole-4-propionate; CB1R, type 1 cannabinoid receptor; Cbln-1, precerebellin; CF-LTD, climbing fiber long term depression; CF-PC, climbing fiber-Purkinje cell; E, embryonic day; LTD, long term depression; LTP, long term potentiation; P, postnatal day; PC, Purkinje cell; PFLTD, parallel fiber long term depression; PF-LTP, parallel fiber long term potentiation; PF-PC, parallel fiber-Purkinje cell; NMDA, $N$-methyl-D-aspartate; NO, nitric oxide; NSF, $N$-ethyl-maleimide-sensitive factor; SCA, spinocerebellar ataxia.

* Corresponding author at: PO Box 30001, 9700 RB Groningen, The Netherlands.

E-mail address: d.s.verbeek@umcg.nl (D.S. Verbeek).

Available online on ScienceDirect (www.sciencedirect.com).

\section{Introduction}

The spinocerebellar ataxias (SCAs) form a group of genetically heterogeneous neurodegenerative disorders causing dysfunction of the cerebellum and loss of motor control in patients. To date, there are 44 different SCA types with as many genetic causes (Table 1). Interestingly, these different genetic variations all result in very similar symptoms of ataxic gait and poor coordination of the hands, speech and eye 
movements, all caused by dysfunction of the cerebellum. This dysfunction is caused by an altered cerebellar output, indicating impairment of the sole output of the cerebellar cortex: Purkinje cells (PCs). This change occurs either because the PCs receive changed input, or because the PCs themselves are impaired, or a combination of both. Because most ataxias display similar symptoms and PC loss, researchers have been looking for common mechanisms on a molecular level. Gene-gene interaction networks have previously shown that even when SCAs are divided into groups based on mutation type, they still show great overlap in gene co-expression mechanisms (Matilla-Dueñas et al., 2013; Smeets

Table 1

Overview of all known mutations causing spinocerebellar ataxia.

\begin{tabular}{|c|c|c|c|c|c|}
\hline $\begin{array}{l}\text { SCA } \\
\text { subtype }\end{array}$ & Gene & Protein & Function & Mutation type & Reference \\
\hline SCA1 & ATXN1 & Ataxin-1 & Transcription regulation & $(\mathrm{CAG})_{\mathrm{n}}$ & (Orr et al., 1993) \\
\hline SCA2 & ATXN2 & Ataxin-2 & RNA metabolism & $(\mathrm{CAG})_{\mathrm{n}}$ & $\begin{array}{l}\text { (Imbert et al., 1996; Pulst et al., } \\
\text { 1996; Sanpei et al., 1996) }\end{array}$ \\
\hline SCA3 & ATXN3 & Ataxin-3 & $\begin{array}{l}\text { Deubiquitination, transcription } \\
\text { regulation }\end{array}$ & $(\mathrm{CAG})_{\mathrm{n}}$ & (Kawaguchi et al., 1994) \\
\hline SCA4 & Unknown & Unknown & Unknown & Unknown & (Flanigan et al., 1996) \\
\hline SCA5 & SPTBN2 & Beta-III Spectrin & Neuronal membrane skeleton & Deletion, MM & (Ikeda et al., 2006) \\
\hline SCA6 & CACNA1A & $\begin{array}{l}\text { Calcium Voltage-gated Channel, P/Q } \\
\text { Type, Alpha } 1 \text { A Subunit }\end{array}$ & Calcium signaling & $(\mathrm{CAG})_{\mathrm{n}}$ & (Zhuchenko et al., 1997) \\
\hline SCA7 & ATXN7 & Ataxin-7 & Transcription regulation & $(\mathrm{CAG})_{\mathrm{n}}$ & (David et al., 1997) \\
\hline SCA8 & KLHL1AS/ATXN8 & Kelch-like 1/Ataxin-8 & Unknown & Intronic $(\mathrm{CTG})_{\mathrm{n}}$ & (Koob et al., 1999) \\
\hline SCA9 & Reserved & Unknown & Unknown & Unknown & (Higgins et al., 1997) \\
\hline SCA10 & ATXN10 & Ataxin-10 & Neuritogenesis & $(\text { ATTCT })_{n}$ & (Matsuura et al., 2000) \\
\hline SCA11 & ТTBK2 & Tau Tubulin Kinase 2 & Implicated in tau phosphorylation & Deletion & (Houlden et al., 2007) \\
\hline SCA12 & PPP2R2B & $\begin{array}{l}\text { Protein phosphatase } 2 \text { (formerly } 2 \mathrm{~A} \text { ), } \\
\text { regulatory subunit B }\end{array}$ & $\begin{array}{l}\text { Regulation of PP2 activity, } \\
\text { transcription regulation }\end{array}$ & $5^{\prime}-\mathrm{UTR}(\mathrm{CAG})_{\mathrm{n}}$ & (Holmes et al., 1999) \\
\hline SCA13 & KCNC3 & $\begin{array}{l}\text { Potassium voltage-gated channel, } \\
\text { Shaw-related subfamily, member } 3\end{array}$ & Potassium signaling & MM & (Waters et al., 2006) \\
\hline SCA14 & PRKCG & Protein kinase C, gamma & Protein phosphorylation & MM & (Chen et al., 2003) \\
\hline SCA15 & ITPR1 & $\begin{array}{l}\text { Inositol 1,4,5-triphosphate receptor, } \\
\text { type } 1\end{array}$ & Calcium signaling & Deletion & (van de Leemput et al., 2007) \\
\hline SCA16 & ITPR1 & $\begin{array}{l}\text { Inositol 1,4,5-triphosphate receptor, } \\
\text { type } 1\end{array}$ & Calcium signaling & Deletion & (Iwaki et al., 2008) \\
\hline SCA17 & TBP & TATA-box-binding protein & Transcription regulation & $(\mathrm{CAG})_{\mathrm{n}}$ & (Nakamura et al., 2001) \\
\hline SCA18 & Unknown & Unknown & Unknown & Unknown & (Devos et al., 2001) \\
\hline SCA19 & KCND3 & $\begin{array}{l}\text { Potassium voltage-gated channel, } \\
\text { Shal-related subfamily, member } 3\end{array}$ & Potassium signaling & MM & (Duarri et al., 2012) \\
\hline SCA20 & Unknown & Unknown & Unknown & Chromosomal Duplication & (Knight et al., 2004) \\
\hline SCA21 & TMEM240 & Synaptic transmembrane protein & Unknown & MM & (Delplanque et al., 2014) \\
\hline SCA22 & KCND3 & $\begin{array}{l}\text { Potassium voltage-gated channel, } \\
\text { Shal-related subfamily, member } 3\end{array}$ & Potassium signaling & MM & (Lee et al., 2012) \\
\hline SCA23 & PDYN & Prodynorphin & Synaptic transmission & MM, frameshift & (Bakalkin et al., 2010) \\
\hline SCA24 & Unknown & Unknown & Unknown & Unknown & (Swartz et al., 2002) \\
\hline SCA25 & Unknown & Unknown & Unknown & Unknown & (Stevanin et al., 2005) \\
\hline SCA26 & eEF2 & $\begin{array}{l}\text { Eukaryotic translation elongation } \\
\text { factor } 2\end{array}$ & Protein synthesis & MM & (Hekman et al., 2012) \\
\hline SCA27 & FGF14 & Fibroblast growth factor 14 & $\begin{array}{l}\text { Signal transduction, regulation of } \\
\text { voltage-gated sodium channels }\end{array}$ & MM & (van Swieten et al., 2003) \\
\hline SCA28 & AFG3L2 & AFG3 ATPase family GENE 3-Like 2 & $\begin{array}{l}\text { ATP-dependent protease essential for } \\
\text { axonal development }\end{array}$ & MM & (Mariotti et al., 2008) \\
\hline SCA29 & ITPR1 & $\begin{array}{l}\text { Inositol 1,4,5-triphosphate receptor, } \\
\text { type } 1\end{array}$ & Calcium signaling & MM & (Huang et al., 2012) \\
\hline SCA30 & Unknown & Unknown & Unknown & Unknown & (Storey et al., 2009) \\
\hline SCA31 & TK2 or BEAN & Unknown & Unknown & Intronic $(\mathrm{TGGAA})_{\mathrm{n}}$ & (Sato et al., 2009) \\
\hline SCA32 & Reserved & & & & \\
\hline SCA33 & Reserved & & & & \\
\hline SCA34 & ELOVL4 & $\begin{array}{l}\text { Elongation of very long chain fatty } \\
\text { acids } \\
\text { protein } 4\end{array}$ & Elongation of fatty acids & MM & (Cadieux-Dion et al., 2014) \\
\hline SCA35 & TGM6 & Transglutaminase 6 & $\begin{array}{l}\text { Crosslinking of proteins, conjugation } \\
\text { of polyamines to proteins }\end{array}$ & MM & (Wang et al., 2010) \\
\hline SCA36 & NOP56 & NOP56 ribonucleoprotein homolog & $\begin{array}{l}\text { 60S ribosomal subunit biogenesis } \\
\text { (early \& middle stages) }\end{array}$ & Intronic $(\mathrm{GGCCTC})_{\mathrm{n}}$ & (Kobayashi et al., 2011) \\
\hline SCA37 & Unknown & Unknown & Unknown & Unknown & (Serrano-Munuera et al., 2013) \\
\hline SCA38 & ELOVL5 & $\begin{array}{l}\text { Elongation of very long chain fatty } \\
\text { acids } \\
\text { protein } 5\end{array}$ & Elongation of fatty acids & MM & (Di Gregorio et al., 2014) \\
\hline SCA39 & Unknown & Unknown & Unknown & Chromosomal duplication & (Johnson et al., 2015) \\
\hline SCA40 & CCDC88C & Coiled-coil domain containing $88 \mathrm{C}$ & $\begin{array}{l}\text { Regulation of protein } \\
\text { phosphorylation, regulation of Wnt } \\
\text { signaling }\end{array}$ & MM & (Tsoi et al., 2014) \\
\hline SCA41 & TRPC3 & $\begin{array}{l}\text { Transient receptor potential cation } \\
\text { channel, subfamily C, member } 3\end{array}$ & $\begin{array}{l}\text { Receptor-activated non-selective } \\
\text { calcium permeant cation channel }\end{array}$ & MM & (Fogel et al., 2015) \\
\hline DRPLA & ATN1 & Atrophin I & Transcriptional corepressor & $(C A G)_{n}$ & (Koide et al., 1994) \\
\hline Undefined & RNF170 & Ring finger protein 170 & E3 ubiquitin ligase activity & MM & (Valdmanis et al., 2011) \\
\hline Undefined & GRID2 & $\begin{array}{l}\text { Glutamate receptor, Ionotropic, } \\
\text { Delta } 2\end{array}$ & $\begin{array}{l}\text { Ionotropic glutamate receptor } \\
\text { activity }\end{array}$ & MM & (Coutelier et al., 2015) \\
\hline
\end{tabular}


and Verbeek, 2014). Gene-gene interaction networks emerging in all cerebellar ataxias include neurogenesis, cell cycle and proliferation, cell communication, and synaptic transmission, all of which include calcium signaling. This suggests that a common molecular mechanism could be found in one of these networks.

Several studies exploring SCA1, SCA7, SCA14 and SCA23 have found problems in synaptic transmission, specifically with one of the excitatory inputs of the cerebellum: the climbing fibers (Duvick et al., 2010; Ebner et al., 2013; Furrer et al., 2013; Perkins et al., 2010; Smeets et al., 2015). Climbing fibers are the axons of inferior olive neurons, and innervate PCs in the cerebellum (Eccles et al., 1966, 1967; Ito, 2006). They exert enormous amount of control over their individual PCs, as will be discussed in this review, and therefore greatly influence the output of the cerebellum. Even though the climbing fiber deficits previously described are not identical, this crucial cerebellar input could be the common ground among SCA pathologies. Finding common underlying pathology could provide insights into key aspects of the disease, and possibly provide therapeutic opportunities for many, if not all, SCA types. Therefore, it would be of great scientific and clinical value to find common pathology before the disease has progressed to PC loss.
Climbing fiber defects have now been detected in mouse models representing four different SCA types, of which two are polyQ (non-conventional) SCA types and two are conventional SCA types. The related disease genes in each type have entirely different functions (Table 1). This presents an opportunity to investigate climbing fibers more closely in relation to cerebellar neurodegeneration and SCA. In this review, we will take a closer look at the development and function of climbing fibers, and their known deficits in SCA1, SCA7, SCA14, and SCA23. We will also discuss the excitatory neurotransmitter glutamate which is utilized by climbing fibers to convey information, and which offers another line of investigation for a shared disease mechanism among SCA types.

\section{Climbing fiber development}

PCs receive input from various cell types. Inhibitory inputs are provided by several types of interneurons in the molecular layer of the cerebellum (Postsynaptic parallel fiber LTD (PF-LTD) has long been described Postsynaptic parallel fiber LTD (PF-LTD) has long been described). Excitatory inputs are provided by parallel fibers and climbing fibers. Parallel fibers are the axons of granule cells located in the

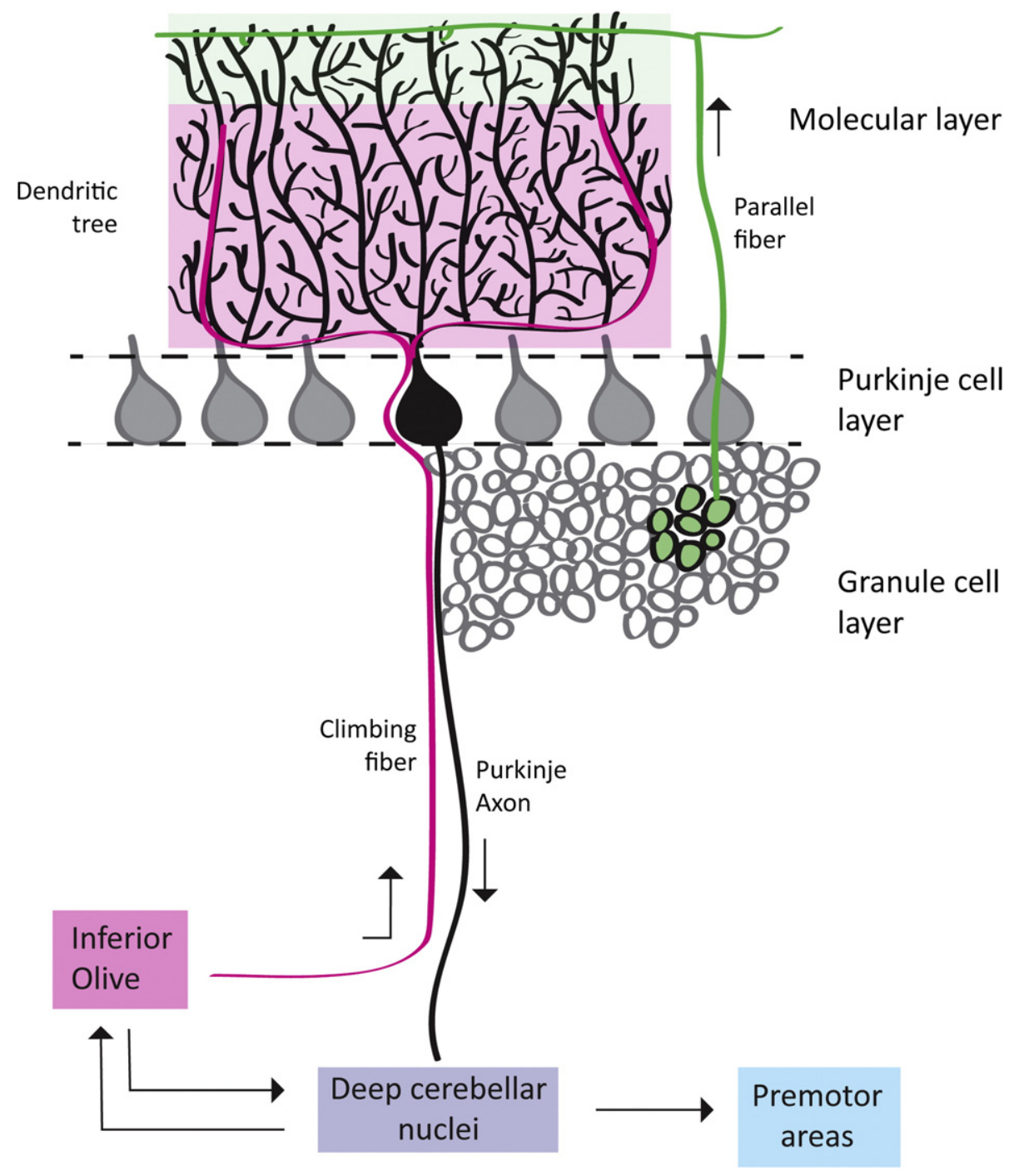

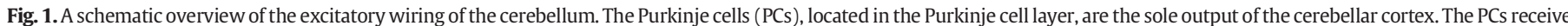

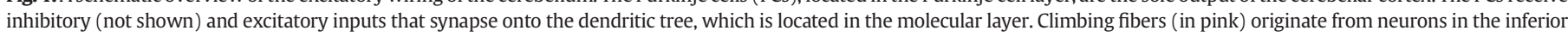

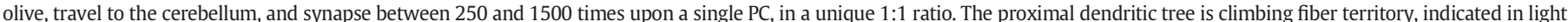

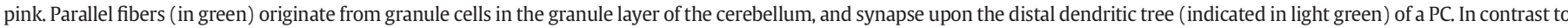

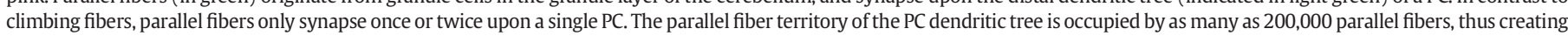
the many PF-PC synapses found on a PC. 
cerebellar granule layer (Fig. 1) and innervate the distal dendritic tree of PCs, with around 200,000 parallel fibers synapsing approximately once or twice upon a PC (Eccles et al., 1967; Ito, 2006). As mentioned in the Introduction section, climbing fibers are the axons of inferior olive neurons, and innervate the proximal PC dendritic tree in a one-to-one ratio, with the climbing fiber synapsing onto the PC between 250 and 1500 times (Eccles et al., 1966, 1967; Hansel and Linden, 2000; Ito, 2006; Konnerth et al., 1990; Najafi and Medina, 2013; Strata and Rossi, 1998; Watanabe and Kano, 2011).

During development, climbing fibers arrive at the cerebellum between embryonic day 15.5 (E15.5) and E16.5 (Kita et al., 2015), when PCs are still migrating (Miyata et al., 2010), and make synaptic contact with PC dendrites rather than soma (Miyata et al., 2010) as early as E16.5 (Kita et al., 2015), however, whether these are functional contacts is not yet known. The postnatal development of climbing fibers has been reviewed extensively by Watanabe and Kano (Watanabe and Kano, 2011). In short, during the first three postnatal weeks, climbing fibers go through six stages of development. During the creeper stage, starting at postnatal day 0 (P0), the fibers creep among PC somata and form transient synapses on the PC's immature dendrites. Around P5, they surround PC somata with a high density and innervate the somata in the pericellular stage. Until approximately P7, PCs are innervated by, on average, five climbing fibers. Between P3 and P7, one of these climbing fibers undergoes functional differentiation and strengthening. Recently, C1q11-Bai3 signaling has been implicated in regulating the selection of "winner" climbing fibers via an anterograde signal supplied by the inferior olive neuron itself, and is required for maintaining the "winner" climbing fiber's synapses from P7 (Kakegawa et al., 2015). The "winner" climbing fiber then starts to displace its synapses to the apical region of the PC soma around P9, during what is called the capuchon stage. By P12, the "winner" climbing fiber will start the dendritic stage of development, meaning it will translocate to the dendrites of the PC and make synapses there.

As soon as one climbing fiber has become the "winner" (around P7), the early phase of climbing fiber synapse elimination starts, lasting until about P11. This process consists of pruning of somatic climbing fiber synapses, and is dependent upon P/Q-type voltage-dependent $\mathrm{Ca}^{2+}$ channels, as evidenced by the improper wiring of climbing fibers in mice lacking the P/Q-type voltage-dependent $\mathrm{Ca}^{2+}$ channel $\mathrm{Ca}_{\mathrm{v}} 2.1$, which is also the channel affected in SCA6 (Miyazaki et al., 2004; Zhuchenko et al., 1997) (Table 1). At the same time, semaphorin3A in PCs acts on plexinA4 on climbing fibers as a retrograde signal to maintain or strengthen the active synapse and prevent elimination (Uesaka et al., 2014, 2015), further strengthening the position of the "winner" climbing fiber. Massive elimination of somatic synapses enables the "winner" climbing fiber to monopolize innervation of its PC in postnatal week 3. Late phase climbing fiber synapse elimination occurs from P12P17 and two mechanisms are currently known to influence this process. The first is the GluR $\delta 2-C b \ln 1$ pathway, wherein GluR $\delta 2$ strengthens parallel fiber-Purkinje cell (PF-PC) synapses structurally while simultaneously weakening these synapses functionally and precerebellin 1 (Cbln1) facilitates synaptic connectivity. Both climbing fiber and parallel fiber innervation are severely altered in GluR82-KO mice, as distal PC dendrites are innervated by climbing fibers instead of parallel fibers (Ichikawa et al., 2002; Miyazaki et al., 2010), and Cbln-null mice show a similar phenotype (Hirai et al., 2005). This mechanism shows the dependence of proper climbing fiber wiring upon parallel fiber synaptogenesis.

In the second mechanism influencing late phase climbing fiber elimination, mGluR1-PKC $\gamma$ signaling plays a central role. The normal development of mGluR1-null mice up to 2 weeks postnatal followed by abnormal synapse elimination towards the end of postnatal week 2, suggests that mGluR1-PKC $\gamma$ signaling is essential for late phase, but not early phase, climbing fiber synapse elimination (Watanabe and Kano, 2011). Incidentally, PF-PC synapse formation is completely normal in these mice, indicating that impaired late phase synapse elimination is not secondary to deficits in parallel fiber synaptogenesis in these mice (Watanabe and Kano, 2011), but is dependent upon mGluR1-PKC $\gamma$ signaling in PCs. Notably, mutations in PKC $\gamma$ cause SCA14 (Table 1). Downstream of mGluR1, semaphorin7A mediates synaptic elimination by acting on plexinC1 and integlinB1 in a retrograde manner (Uesaka et al., 2014, 2015), further indicating the importance of mGluR1 signaling in this process, with the suggestion that mGluR1semaphorin7A signaling promotes elimination rather than shielding "winner" synapses from elimination. This hypothesis was strengthened by the recent observation that C1ql1-Bai3 signaling maintains "winner" climbing fiber synapses independently from mGluR1 signaling, and typically on the more distal climbing fiber-Purkinje cell (CF-PC) synapses (Kakegawa et al., 2015).

\section{Climbing fiber activation}

The activation of a climbing fiber has a dual role: 1) triggering synaptic plasticity at dendritic PC synapses (see Synaptic plasticity and climbing fiber control, below) and 2) generating a distinct output in the PC axon, the complex spike (Davie et al., 2008; Eccles et al., 1966; Miyakawa et al., 1992; Tsutsumi et al., 2015). The complex spike represents a critical signal for cerebellar functioning, conveying timing information for motor function (Welsh and Llinás, 1997). It consists of a fast initial spike followed by several slower spikelets with smaller amplitudes, separated by $2-3 \mathrm{~ms}$ (Eccles et al., 1966). The initial fast spike is caused by opening of the $\alpha$-amino-3-hydroxy-5-methylisoxazole-4propionate (AMPA) receptors at the CF-PC synapse (Watanabe and Kano, 2011), while the smaller spikelets are the result of interaction between local sodium currents in the PC soma (Raman and Bean, 1997, 1999a, 1999b; Schmolesky et al., 2002) and the typical activation of climbing fibers, which tend to fire in high-frequency bursts of 1 to 6 spikes (Mathy et al., 2009). As the complex spike is crucial for cerebellar functioning and motor control, inadequate generation of complex spikes would cause abnormal cerebellar functioning and ataxic phenotypes. Whether the character of climbing fiber activation is "all-or-nothing" or more graded, so as to encode more information, is still being debated (for a review, see (Najafi and Medina, 2013)). However, more evidence of pre- and postsynaptic modulation is emerging, making the case for a graded, more instructive complex spike (Najafi and Medina, 2013).

\section{Synaptic plasticity and climbing fiber control}

Pre- and post-synaptic modulation consist of long-term potentiation (LTP) and long-term depression (LTD) of the excitatory synaptic inputs of the PC, namely the climbing and parallel fibers. Synaptic plasticity is of great importance to the functioning of the cerebellum, as it has long been implicated in motor functioning and learning (Hansel et al., 2001; Hirano, 2013; Ito, 1982; Linden and Connor, 1995; Titley and Hansel, 2015; Wang et al., 2013). Changes in the efficiency of specific synapses can change the content of the message entirely. Of course, if the changed synaptic efficiency is physiological and intentional, it can be very useful. However, when the changes are pathological, they can unravel the finely tuned cerebellar neuronal machinery quite quickly.

The parallel fiber-Purkinje cell (PF-PC) synapse can express LTD pre(Chu et al., 2014; Qiu and Knöpfel, 2008; Titley and Hansel, 2015) and post-synaptically (Hansel and Linden, 2000; Hansel et al., 2001; Ito, 1982; Linden, 2001, 2003; Wang et al., 2000), as well as LTP pre(Chen and Regehr, 1997; Hansel et al., 2001; Jacoby et al., 2001; Linden and Ahn, 1999; Najafi and Medina, 2013; Salin et al., 1996; Storm et al., 1998) and postsynaptically (Belmeguenai and Hansel, 2005; Coesmans et al., 2004; Lev-Ram et al., 2002, 2003; Schonewille et al., 2010; Wang et al., 2014). CF-PC synapses can express LTD postsynaptically (Hansel and Linden, 2000; Hansel et al., 2001; Weber et al., 2003). These processes are reviewed in detail below. An overview can be found in Table 2 . 
Table 2

Overview of the different forms of synaptic plasticity.

\begin{tabular}{|c|c|c|c|}
\hline Synapse & Plasticity & Critical molecules & Effect/expression \\
\hline PF-PC & Post-synaptic LTD & $\begin{array}{l}\text { mGluR1 } \\
\text { AMPA receptors } \\
\mathrm{Ca}^{2+} \uparrow \uparrow \\
\mathrm{cPLA} 2 \alpha \\
\mathrm{CB} 1 \mathrm{R} \\
\text { NMDA receptors }\end{array}$ & $\begin{array}{l}\text { Reduced post-synaptic expression of AMPARs leading to reduced excitability } \\
\text { probability }\end{array}$ \\
\hline PF-PC & Post-synaptic LTP & $\begin{array}{l}\mathrm{Ca}^{2+} \uparrow \\
\text { cPLA2 } \alpha \\
\text { CB1R } \\
\text { NO } \\
\text { NSF }\end{array}$ & $\begin{array}{l}\text { Increased post-synaptic expression of AMPARs leading to increased } \\
\text { excitability probability }\end{array}$ \\
\hline PF-PC & Pre-synaptic LTD & $\begin{array}{l}\text { CB1R } \\
\text { NMDA receptors } \\
\text { NO synthase }\end{array}$ & Unknown \\
\hline PF-PC & Pre-synaptic LTP & $\begin{array}{l}\text { Adenylyl cyclase I } \\
\text { PKA }\end{array}$ & Decreased rate of synaptic failures \\
\hline CF-PC & Post-synaptic LTD & $\begin{array}{l}\text { mGluR1 } \\
\mathrm{Ca}^{2+} \uparrow \uparrow \\
\mathrm{PKC}\end{array}$ & $\begin{array}{l}\text { Reduced post-synaptic expression of AMPARs leading to reduced excitability } \\
\text { probability, and consequently reduced probability of induction of } \\
\text { postsynaptic PF-LTD }\end{array}$ \\
\hline
\end{tabular}

\subsection{Postsynaptic parallel fiber long-term depression}

Postsynaptic parallel fiber LTD (PF-LTD) has long been described as a mechanism for cerebellar motor learning (Ito, 1982; Linden and Connor, 1995; Titley and Hansel, 2015), and is dependent upon the simultaneous activation of climbing and parallel fibers (Hansel et al., 2001; Ito, 1982; Linden, 2003; Wang et al., 2000). At the PF-PC synapse, glutamate acts upon mGluR1 and AMPA receptors, increasing intracellular calcium levels. Combined with the complex spike generated by climbing fiber generation, the intracellular calcium levels in the PC are pushed to the high threshold needed for PF-LTD induction (Coesmans et al., 2004; Hansel et al., 2001). Subsequently, PKC $\gamma$ and $\alpha$ CaMKII are activated (De Zeeuw et al., 1998; Hansel et al., 2001, 2006; Leitges et al., 2004; Linden and Connor, 1991), as well as several other signaling cascades, including $\mathrm{cPLA}_{2} \alpha / \mathrm{COX} 2$, cannabinoid receptor 1 (CB1R), $N$-methyl-D-aspartate (NMDA) receptors, and nitric oxide (NO) (Casado et al., 2002; Hansel et al., 2001; Le et al., 2010; Lev-Ram et al., 1995, 1997; Safo and Regehr, 2005; Shin and Linden, 2005). These signaling cascades ultimately lead to a reduction in the number of functional AMPA receptors at the postsynaptic membrane of the PF-PC synapse (Hansel et al., 2001; Wang and Linden, 2000; Xia et al., 2000), thus making excitation of the postsynaptic membrane less likely during activation of the parallel fiber. However, a recent publication proposed that PF-LTD is facilitated by AMPA receptors (van Beugen et al., 2014), suggesting that the expression of functional AMPA receptors at the post-synaptic membrane is not completely lost during PF-LTD. Furthermore, the degree of activation of mGluR1 is important during the critical stages of postsynaptic LTD induction, as increased activation of mGluR1 has been shown to facilitate this process at both excitatory inputs of the PC (Brasnjo and Otis, 2001; Su and Shen, 2009).

\subsection{Postsynaptic parallel fiber long-term potentiation}

Postsynaptic parallel fiber LTP (PF-LTP) can reverse its counterpart, postsynaptic PF-LTD, as it has been shown that PF-LTP causes extinction of learned associations in trained animals (Han et al., 2000; Medina et al., 2000; Schonewille et al., 2010). Postsynaptic PF-LTP requires a lower calcium threshold than postsynaptic PF-LTD (Coesmans et al., 2004), and is induced via low frequency stimulation of parallel fibers (Belmeguenai and Hansel, 2005; Lev-Ram et al., 2002; Schonewille et al., 2010; Wang et al., 2014). Low frequency parallel fiber stimulation subsequently leads to activation of $\mathrm{CPLA}_{2} \alpha$, resulting in liberation of arachidonic acid and the production of 2-arachidonolylglycerol, which binds presynaptic type 1 cannabinoid receptors (CB1Rs) in a retrograde manner (Wang et al., 2014). Activation of the CB1R then triggers NO activation, leading to low levels of NO anterogradely crossing the synapse (Lev-Ram et al., 2002, 2003; Wang et al., 2014). At the postsynaptic membrane, it promotes nitrosylation of $\mathrm{N}$-ethyl-maleimide-sensitive factor (NSF) (Huang et al., 2005; Titley and Hansel, 2015), which in turn binds the AMPA receptor subunit GluR2 and mediates insertion of AMPA receptors into the membrane (Hansel, 2005; Kakegawa and Yuzaki, 2005; Titley and Hansel, 2015). Postsynaptic PF-LTP is thus expressed as an increase in functional AMPA receptors at the postsynaptic membrane, and is clearly the cellular inverse of postsynaptic PF-LTD. Interestingly, postsynaptic PF-LTP and PF-LTD share a number of critical molecules, including calcium, $\mathrm{CPLA}_{2} \alpha, \mathrm{CB} 1 \mathrm{R}$ and NO. A notable divergence is glutamate binding to mGluR1 and NMDA receptors, which PF-LTD is dependent upon, but PF-LTP is not (Belmeguenai et al., 2008; Brasnjo and Otis, 2001; He et al., 2013; Piochon et al., 2010; Takechi et al., 1998). However, in a SCA5 mouse model expression mutant BIII-spectrin, mGluR1 shows altered localization, and mGluR1mediated postsynaptic PF-LTP is deficient (Armbrust et al., 2014). Furthermore, $\mathrm{CPLA}_{2} \alpha$ and CB1R may play dual roles in synaptic plasticity (Daniel et al., 2004; Le et al., 2010; Levenes et al., 1998; Safo and Regehr, 2005; Takahashi and Linden, 2000; van Beugen et al., 2006; Wang et al., 2014), as does calcium -and therefore climbing fiber activity- which is considered to be a deciding factor in the induction of LTP or LTD (Coesmans et al., 2004; Titley and Hansel, 2015).

\subsection{Presynaptic parallel fiber long-term depression}

The presynaptic form of PF-LTD has been less well studied. It involves endocannabinoid signaling and presynaptic CB1R activation, is dependent upon NMDA receptor activation, and upregulated by NO synthase, while a consensus has not yet been reached on the involvement of mGluR1 (Chu et al., 2014; Qiu and Knöpfel, 2008; Titley and Hansel, 2015). It is also currently unclear which physiological conditions require this type of synaptic plasticity (Titley and Hansel, 2015).

\subsection{Presynaptic parallel fiber long-term potentiation}

Presynaptic PF-LTP is evoked by 4-8 Hz parallel fiber stimulation, and depends on the activation of calcium/calmodulin-sensitive adenylyl cyclase I and the subsequent activation of cAMP-dependent kinase protein A (PKA) (Chen and Regehr, 1997; Hansel et al., 2001; Jacoby et al., 2001; Linden and Ahn, 1999; Salin et al., 1996; Storm et al., 1998). It is associated with a decrease in the rate of synaptic failures and the extent of paired-pulse facilitation (Hansel et al., 2001). 


\subsection{Postsynaptic climbing fiber long-term depression}

Climbing fibers can express postsynaptic LTD, and similarly to postsynaptic PF-LTD, CF-LTD requires post-synaptic $\mathrm{Ca}^{2+}$ influx and activation of mGluR1 and PKC (Hansel and Linden, 2000; Ohtsuki et al., 2009; Shen et al., 2002), with both expressed as a reduced number of AMPA receptors at the postsynaptic membrane (Shen et al., 2002). The consequences of CF-LTD are a reduction in the slow component of the complex spike (Hansel and Linden, 2000; Weber et al., 2003), a reduction in the complex spike afterhyperpolarization (Schmolesky et al., 2005), and decreased complex spike-evoked dendritic $\mathrm{Ca}^{2+}$ transients (Weber et al., 2003), all of which reduce the probability of subsequent induction of parallel fiber plasticity requiring a high calcium threshold (Ohtsuki et al., 2009; Weber et al., 2003). In addition, CF-LTD is not associated with changes in the synaptic glutamate transient (Shen et al., 2002). The observed decrease in complex spike-evoked $\mathrm{Ca}^{2+}$ transients (Weber et al., 2003) has a significant effect on the probability for PF-LTD induction (Coesmans et al., 2004), could have a neuroprotective function (Coesmans et al., 2004) and/or could provide a critical component of cerebellar learning (Ohtsuki et al., 2009).

\subsection{The climbing fiber as control switch}

The PF-PC synapse is clearly a very plastic synapse. However, neither the parallel fiber nor the PC have much control over this plasticity. The regulation of these processes seems to be mostly outsourced to the climbing fiber, which acts as a control switch. Climbing fiber activation evokes complex spikes and, consequently, large dendritic calcium transients, triggering postsynaptic PF-LTD induction, whereas the absence of complex spikes during climbing fiber inactivity leads to the induction of postsynaptic PF-LTP (Coesmans et al., 2004). Changes in climbing fibers can therefore lead to altered synaptic plasticity and cause an ataxic phenotype, which will be discussed in the section on "Climbing fiber deficits and glutamate dysregulation in mouse models of spinocerebellar ataxia". Furthermore, to create a sort of "safety lock" to prevent simultaneous induction of pre- and postsynaptic plasticity, presynaptic PF-LTP is also under the influence of climbing fiber activity (van Beugen et al., 2006). Climbing fiber activity can trigger endocannabinoid release at the PF-PC synapse (Brenowitz and Regehr, 2003, 2005; Kreitzer and Regehr, 2001) and in a retrograde manner bind and activate CB1R, which then blocks adenylyl cyclase I to suppress presynaptic PF-LTP while PF-LTD is expressed postsynaptically (van Beugen et al., 2006). Without this "safety lock", the decrease in response elements during postsynaptic PF-LTD could be accompanied by an increase in neurotransmitter release, nullifying the effect of reducing postsynaptic AMPA receptors.

\section{The importance of glutamate and calcium in synaptic plasticity}

Climbing fibers exert a lot of control over the plasticity of the excitatory synapses onto the PC and, because climbing fibers are themselves excitatory inputs, glutamate plays a major role in controlling plasticity. During climbing fiber activation, multiple glutamate-containing vesicles are released into the synaptic cleft (Wadiche and Jahr, 2001), where there are at least three types of glutamate receptors present: AMPA receptors, NMDA receptors and mGluRs. The AMPA receptors located at the CF-PC synapse largely mediate EPSCs (Konnerth et al., 1990; Llano et al., 1991; Perkel et al., 1990), and do not contribute to the PC calcium surge because they contain the GluD2 subunit, which makes them impermeable to $\mathrm{Ca}^{2+}$ (Hollmann et al., 1991). NMDA receptors are expressed in mature PCs and, next to the NR1 subunit, mostly contain subunits NR2A and NR2B (Piochon et al., 2007; Renzi et al., 2007). NMDA receptors are activated by climbing fiber stimulation, and influence the number and timing of spikelets, thereby contributing to the complex spike waveform (Piochon et al., 2007). NMDA receptors are permeable to $\mathrm{Ca}^{2+}$ (Mayer and Westbrook, 1987), and therefore likely contribute to the postsynaptic $\mathrm{Ca}^{2+}$ surge associated with climbing fiber activation and postsynaptic LTD induction. As discussed earlier (in the sections on "Postsynaptic parallel fiber long-term depression" and "Postsynaptic climbing fiber long-term depression"), mGluR1 is critical for induction of postsynaptic LTD at both PF- and CF-PC synapses, as mGluR1 potentials significantly enhance complex spike-associated $\mathrm{Ca}^{2+}$ transients throughout the PC dendrite (Yuan et al., 2007). mGluR1 signaling has two paths: IP3-mediated $\mathrm{Ca}^{2+}$ release from internal stores and activation of transient receptor potential canonical (TRPC) channels. Because the IP3 receptor (mutated in SCA15 and SCA16 (Iwaki et al., 2008; van de Leemput et al., 2007)) expressed in PCs has a remarkably low sensitivity to IP3 (Finch and Augustine, 1998), it is much more likely that mGluR1 synaptic transmission is mediated by TRPC3 (Hartmann et al., 2008; Kim, 2013), a non-selective cation channel with a high permeability for calcium (Kamouchi et al., 1999) and high expression in the cerebellum (Riccio et al., 2002). Interestingly, Moonwalker mice (mice with a mutation in the SCA41 gene TRPC3 (Fogel et al., 2015)) and Trpc3 knockout mice demonstrate ataxic phenotypes, with the Moonwalker having a more severe phenotype (Becker, 2014; Dulneva et al., 2015). Additionally, glutamate transporters play an important role in synaptic plasticity by controlling the amount of glutamate available in the synaptic cleft and, indirectly, the degree of activation of mGluR1 (Brasnjo and Otis, 2001; Su and Shen, 2009). Thus, a major consequence of glutamate-mediated transmission is clearly an increase in intracellular calcium. To reduce intracellular $\mathrm{Ca}^{2+}$ and prevent excitotoxicity, PCs express an abundance of $\mathrm{Ca}^{2+}$ binding EF-hand protein buffers, $\mathrm{Ca}^{2+}$ pumps and exchangers (for review see (Arundine and Tymianski, 2003; Wojda et al., in review)). However, in such a highly regulated environment, the slightest change in $\mathrm{Ca}^{2+}$ buffering capacity due to extra- or intracellular changes may cause or further PC dysfunction (Matilla-Dueñas et al., 2014). Furthermore, it has been proposed that changes in cellular functions directly or indirectly leading to $\mathrm{Ca}^{2+}$ dysregulation are eventually responsible for dark cell degeneration (Kasumu and Bezprozvanny, 2012), a type of cell death observed in mouse models of SCA1, SCA2, SCA3, SCA5, SCA7, SCA28, and AMPA-induced delayed excitotoxicity and of hypoxia (Matilla-Dueñas et al., 2014; Perkins et al., 2010), to which PCs seem to be particularly sensitive.

\section{Climbing fiber deficits and glutamate dysregulation in mouse models of spinocerebellar ataxia}

In mouse models of SCA1, SCA7, SCA14, and SCA23 climbing fiber deficits have been found. These deficits range from developmental changes to retraction of climbing fibers in adult mice. In addition, mouse models for SCA5 and SCA28 display alterations in glutamate signaling, a finding which is in line with climbing fiber deficits, as both result in PC dysfunction.

Mouse models for SCA1 expressing expanded ATXN1[82Q] exhibit abnormal motor behavior by 6 weeks of age, including slightly reduced cage activity, gentle swaying of the head while walking, and early signs of general incoordination, accompanied with mild PC dysfunction (Burright et al., 1995), and PC loss around 24 weeks of age (Barnes et al., 2011). In addition to PC dysfunction, climbing fiber deficits are a critical component of the SCA1 pathology, and can be observed around 6 weeks of age, long before PC loss begins (Barnes et al., 2011; Duvick et al., 2010; Ebner et al., 2013). These transgenic mice demonstrate diminished arborization of climbing fibers along PC dendrites (Duvick et al., 2010), a reduction in PC responsiveness to climbing fiber activation (Barnes et al., 2011; Ebner et al., 2013) and, perhaps most importantly, compromised development of climbing fibers as indicated by reduced ascension and disrupted pruning of climbing fiber termini on PC somata and apical dendrites (Ebner et al., 2013). CF-PC synaptic transmission deficits required ATXN1[82Q] to be located in the nucleus, suggesting $A T X N 1[82 \mathrm{Q}]$ alters the expression of one or more genes in the PC that are crucial for its innervation by climbing fibers (Ebner 
et al., 2013). The simultaneous appearance of abnormal phenotypical behavior and climbing fiber deficits suggests that these deficits are a likely cause of the ataxic phenotype of SCA1 transgenic mice.

Conditional transgenic mice expressing mutant ATXN7[92Q] are a model for SCA7, and demonstrate progressive ataxia and impaired motor function starting at 20 weeks of age, and loss of Calbindin - a PC marker - at 40 weeks of age (Furrer et al., 2011). Examination of the CF-PC synapses showed proximal aggregation of climbing fiber synapses at 40 weeks of age in transgenic mice, while 20 -week-old transgenic mice display normal climbing fiber morphology (Furrer et al., 2013), suggesting that expression of mutant ataxin-7 causes redistribution of climbing fiber termini between 20 and 40 weeks of age in mice. Interestingly, SCA7 mutant mice display an ataxic phenotype before changes in climbing fiber distribution can be observed. It is possible that in SCA7, pathology is caused by dysfunction of PCs mediated by dysfunction of Bergmann glia, which clear excess glutamate from the CF-PC synaptic cleft. If excess glutamate is not effectively cleared, this can affect $\mathrm{Ca}^{2+}$ signaling in the PC and lead to PC dysfunction.

A mouse model for SCA14 has been generated by injection of a lentiviral vector expressing mutant PKC $\gamma$ into the cerebellar cortex (Shuvaev et al., 2011). One-week-old mice lentivirally treated with mutant PKC $\gamma$ spent less time on an accelerating rotarod than age-matched non-treated mice, whereas mice treated at P21-P25 did not display an ataxic phenotype (Shuvaev et al., 2011). Injection of lentivirus during the development of climbing fibers (P6-7) caused PCs expressing mutant PKC $\gamma$ to be innervated by multiple climbing fibers, while injection after maturation of climbing fibers (P21-25) did not (Shuvaev et al., 2011), indicating early expression of mutant PKC $\gamma$ impairs determination of a "winner" climbing fiber. Postsynaptic PF-LTD could not be induced in either model, while presynaptic PF-LTD was not disrupted (Shuvaev et al., 2011), which could be expected, as PKC $\gamma$ is involved in postsynaptic, but not presynaptic, PF-LTD. These models suggest that even when climbing fibers develop normally, the CF-PC synapse cannot function properly when mutant PKC $\gamma$ is expressed. Therefore, in SCA14, as in SCA1, SCA7, and SCA23, one change in the highly regulated process of synaptic plasticity is the likely cause of the typical ataxic phenotype.

The transgenic mice modeling SCA23 expresses mutant Prodynorphin, and displays a slowly progressive spinocerebellar ataxia starting at 3 months of age, with mild PC loss at 12 months of age and progressive retraction of climbing fibers starting at 3 months of age (Smeets et al., 2015). In these mice, climbing fibers retract from the PC dendrite due to expression of mutant Prodynorphin and, consequently, secretion of mutant peptide Dynorphin A, leading to deficits in synaptic transmission. Interestingly, climbing fiber pathology is mainly restricted to the anterior vermis of the SCA23 cerebellum, and coincides with the onset of the ataxic phenotype (Smeets et al., 2015) suggesting that, as in SCA1, it is not PC loss but climbing fiber deficits that are a likely cause of the pathological phenotype.

Spnb3 $3^{-1-}$ mice expressing low levels of truncated BIII-spectrin are a model for SCA5, and are prone to a mild, non-progressive ataxia and stimulus-induced seizures starting between 6 and 8 months of age (Stankewich et al., 2010), while mice completely lacking BIII-spectrin model SCA5 by displaying gait abnormalities, tremor, deteriorating motor coordination, Purkinje cell loss and cerebellar atrophy (Perkins et al., 2010). Spectrins are important structural proteins of the plasma membrane skeleton, and control the disposition of selected membrane channels, receptors, and transporters. BIII spectrin is found on PC somata and dendrites, and it directly binds to glutamate transporter EAAT4, GluR82, and other proteins (Perkins et al., 2010; Stankewich et al., 2010). Spnb3 $3^{-1-}$ mice do not show specific climbing fiber deficits up to one year of age, however, their $\beta$ III spectrin deficiency diminished, among other factors, the EAAT4 and GluR $\delta 2$ expression at the postsynaptic membrane (Stankewich et al., 2010). Interestingly, in mice lacking BIII-spectrin, PF-LTD has been shown not to be impaired (Gao et al., 2011). Nonetheless, this is another mutation causing spinocerebellar ataxia that leads to changes in glutamate (and therefore calcium) signaling disrupting the delicate balance of synaptic plasticity in the cerebellum.

A mouse model for SCA28, haploinsufficient for mitochondrial protease $A f g 3 l 2$, also demonstrated problems with glutamate homeostasis. These mice exhibit a progressive decline in motor function and dark cell degeneration of mitochondrial origin from 8 months of age onward (Maltecca et al., 2015). AFG3L2 is part of a quality control protein complex located on the inner membrane of the mitochondrium, which selectively degrades damaged proteins, exerts a chaperone-like activity on respiratory chain complexes, and is essential for axonal development (Arlt et al., 1998; Atorino et al., 2003; Koppen and Langer, 2007; Maltecca et al., 2008). In cultured Afg3l2-deficient PCs, mitochondria ineffectively buffer $\mathrm{Ca}^{2+}$ peaks, resulting in increased intracellular $\mathrm{Ca}^{2+}$ levels, triggering PC dark cell degeneration. Partial genetic silencing of mGluR1 or treatment with ceftriaxone, an antibiotic that promotes synaptic clearance of glutamate, reduced $\mathrm{Ca}^{2+}$ influx into PCs, and improved ataxic phenotypes in SCA28 mice (Maltecca et al., 2015). This indicates that glutamate dysregulation is a hallmark of SCA28 as well.

In addition, recently, three new mutations in GRID2 encoding GluR $\delta 2$ were identified in a large Algerian family with adult-onset slowly progressive ataxia in seven adults and congenital ataxia in one child and in a large cohort of congenital ataxia patients (Coutelier et al., 2015). In the Algerian family, the Leu656Val mutation was identified, and found to be heterozygous in the adult patients but homozygous in the child with congenital ataxia. This mutation is located in the third transmembrane domain of GluR $\delta 2$, which is involved in transmission of information between the ligand-binding domain and the pore, and AMPA receptor trafficking. In the congenital ataxia cohort, two de novo missense mutations were identified: Ala654Thr and Ala654Asp (Coutelier et al., 2015). Interestingly, these mutations affect the same amino acid as the well-known Lurcher mutation, and Ala654Thr is actually the same mutation (Zuo et al., 1997). The affected amino acid is located in the highly conserved SYTANLAAF motif, crucial for gating of the channel, and mutations in this motif in other ionotropic glutamate receptor subunits are known to change channel function significantly (Chang and Kuo, 2008; Murthy et al., 2012; Yuan et al., 2014). Lurcher mouse PCs have been shown to have increased conductance, giving rise to a constitutively active inward current, which is not affected by the presence of glutamate, but reduced when extracellular $\mathrm{Na}^{+}$is replaced with $N$-methyl-D-glucamine, a relatively large organic cation (Zuo et al., 1997), indicating the channel is constitutively open. These changes in PC conductivity suggest changes in membrane depolarization and $\mathrm{Ca}^{2+}$ transients, and therefore changes in PC functioning.

\section{Conclusion}

The cerebellar circuitry is a finely tuned neuronal machine, crucial for motor learning and functioning. We discussed how climbing fibers are an important part of the machinery and any changes in their development or physiology can be catastrophic for cerebellar functioning. Not only are the climbing fibers a major excitatory input for the PC, they also exert an enormous amount of control over the other excitatory PC input, the parallel fibers and their synaptic plasticity. This synaptic plasticity is another crucial factor for normal cerebellar function and motor behavior. When any component of the highly regulated processes in the cerebellum is altered the consequences for neural functioning are catastrophic.

The disorders discussed here are all caused by mutations in different genes (Table 1), but they all lead to a disruption of the same cerebellar synapse. This is a very interesting phenomenon, and suggests this may be a common pathology among the SCAs. As has been demonstrated, it is PC dysfunction rather than PC loss that gives rise to the symptoms of ataxia, and climbing fibers play a major role in the proper functioning of PCs. Having much of the control over induction of plasticity in both parallel fibers and climbing fibers, the climbing fibers have control 
over the excitability of the PC and, consequently, over cerebellar output and motor control. Of course, improper execution of motor function is a central symptom in ataxia, which could be explained in part by dysfunctional climbing fibers. However, further research is needed to determine whether climbing fibers and glutamate signaling really form some common ground underlying the spinocerebellar ataxias, and whether this phenomenon could be useful as a therapeutic target. Additionally, genes with functions in the CF-PC synapse and glutamate signaling may be candidate disease genes for ataxia cases without a genetic diagnosis.

\section{Acknowledgments}

This work was funded by a Rosalind Franklin Fellowship from the University of Groningen, a grant from the Jan Kornelis de CockStichting (2015-79), and the U4 PhD Program of the Behavioral and Cognitive Neuroscience Graduate School of the University of Groningen (022.004.008)

We would like to thank Jackie Senior and Kate McIntyre for editing this manuscript.

\section{References}

Arlt, H., Steglich, G., Perryman, R., Guiard, B., Neupert, W., Langer, T., 1998. The formation of respiratory chain complexes in mitochondria is under the proteolytic control of the $\mathrm{m}$ AAA protease. EMBO J. 17, 4837-4847. http://dx.doi.org/10.1093/emboj/17.16.4837.

Armbrust, K.R., Wang, X., Hathorn, T.J., Cramer, S.W., Chen, G., Zu, T., Kangas, T., Zink, A.N., Öz, G., Ebner, T.J., Ranum, L.P.W., 2014. Mutant $\beta$-III spectrin causes mGluR1 $\alpha$ mislocalization and functional deficits in a mouse model of spinocerebellar ataxia type 5. J. Neurosci. 34, 9891-9904. http://dx.doi.org/10.1523/JNEUROSCI.0876-14. 2014.

Arundine, M., Tymianski, M., 2003. Molecular mechanisms of calcium-dependent neurodegeneration in excitotoxicity. Cell Calcium 34, 325-337. http://dx.doi.org/10.1016/ S0143-4160(03)00141-6.

Atorino, L., Silvestri, L., Koppen, M., Cassina, L., Ballabio, A., Marconi, R., Langer, T., Casari, G., 2003. Loss of m-AAA protease in mitochondria causes complex I deficiency and increased sensitivity to oxidative stress in hereditary spastic paraplegia. J. Cell Biol. 163, 777-787. http://dx.doi.org/10.1083/jcb.200304112.

Bakalkin, G., Watanabe, H., Jezierska, J., Depoorter, C., Verschuuren-Bemelmans, C., Bazov, I., Artemenko, K.A., Yakovleva, T., Dooijes, D., Van de Warrenburg, B.P.C., Zubarev, R.A. Kremer, B., Knapp, P.E., Hauser, K.F., Wijmenga, C., Nyberg, F., Sinke, R.J., Verbeek, D.S., 2010. Prodynorphin mutations cause the neurodegenerative disorder spinocerebellar ataxia type 23. Am. J. Hum. Genet. 87, 593-603. http://dx.doi.org/10.1016/j.ajhg. 2010.10.001.

Barnes, J.A., Ebner, B.A., Duvick, L.A., Gao, W., Chen, G., Orr, H.T., Ebner, T.J., 2011. Abnormalities in the climbing fiber-purkinje cell circuitry contribute to neuronal dysfunction in ATXN1[82Q] mice. J. Neurosci. 31, 12778-12789. http://dx.doi.org/10.1523/ JNEUROSCI.2579-11.2011.

Becker, E.B.E., 2014. The moonwalker mouse: new insights into TRPC3 function, cerebellar development, and ataxia. Cerebellum 13, 628-636. http://dx.doi.org/10.1007/ s12311-014-0564-5.

Belmeguenai, A., Hansel, C., 2005. A role for protein phosphatases 1, 2A, and 2B in cerebellar long-term potentiation. J. Neurosci. 25, 10768-10772. http://dx.doi.org/10.1523/ JNEUROSCI.2876-05.2005.

Belmeguenai, A., Botta, P., Weber, J.T., Carta, M., De Ruiter, M., De Zeeuw, C.I., Valenzuela C.F., Hansel, C., 2008. Alcohol impairs long-term depression at the cerebellar parallel fiber-Purkinje cell synapse. J. Neurophysiol. 100, 3167-3174. http://dx.doi.org/10. $1152 /$ jn.90384.2008

Brasnjo, G., Otis, T.S., 2001. Neuronal glutamate transporters control activation of postsynaptic metabotropic glutamate receptors and influence cerebellar long-term depression. Neuron 31, 607-616.

Brenowitz, S.D., Regehr, W.G., 2003. Calcium dependence of retrograde inhibition by endocannabinoids at synapses onto Purkinje cells. J. Neurosci. 23, 6373-6384.

Brenowitz, S.D., Regehr, W.G., 2005. Associative short-term synaptic plasticity mediated by endocannabinoids. Neuron 45, 419-431. http://dx.doi.org/10.1016/j.neuron. 2004.12.045.

Burright, E.N., Clark, H.B., Servadio, A., Matilla, T., Feddersen, R.M., Yunis, W.S., Duvick, L.A., Zoghbi, H.Y., Orr, H.T., 1995. SCA1 transgenic mice: a model for neurodegeneration caused by an expanded CAG trinucleotide repeat. Cell 82, 937-948.

Cadieux-Dion, M., Turcotte-Gauthier, M., Noreau, A., Martin, C., Meloche, C., Gravel, M. Drouin, C.A., Rouleau, G.A., Nguyen, D.K., Cossette, P., 2014. Expanding the clinical phenotype associated with ELOVL4 mutation: study of a large French-Canadian family with autosomal dominant spinocerebellar ataxia and erythrokeratodermia. JAMA Neurol. 71, 470-475. http://dx.doi.org/10.1001/jamaneurol.2013.6337.

Casado, M., Isope, P., Ascher, P., 2002. Involvement of presynaptic N-methyl-D-aspartate receptors in cerebellar long-term depression. Neuron 33, 123-130.

Chang, H.-R., Kuo, C.-C., 2008. The activation gate and gating mechanism of the NMDA receptor. J. Neurosci. 28, 1546-1556. http://dx.doi.org/10.1523/JNEUROSCI.3485-07. 2008.
Chen, C., Regehr, W.G., 1997. The mechanism of cAMP-mediated enhancement at a cerebellar synapse. J. Neurosci. 17, 8687-8694.

Chen, D.-H., Brkanac, Z., Verlinde, C.L.M.J., Tan, X.-J., Bylenok, L., Nochlin, D., Matsushita, M., Lipe, H., Wolff, J., Fernandez, M., Cimino, P.J., Bird, T.D., Raskind, W.H., 2003. Missense mutations in the regulatory domain of PKC gamma: a new mechanism for dominant nonepisodic cerebellar ataxia. Am. J. Hum. Genet. 72, 839-849.

Chu, C.-P., Zhao, G.-Y., Jin, R., Zhao, S.-N., Sun, L., Qiu, D.-L., 2014. Properties of 4 Hz stimulation-induced parallel fiber-Purkinje cell presynaptic long-term plasticity in mouse cerebellar cortex in vivo. Eur. J. Neurosci. 39, 1624-1631. http://dx.doi.org/ 10.1111/ejn.12559.

Coesmans, M., Weber, J.T., De Zeeuw, C.I., Hansel, C., 2004. Bidirectional parallel fiber plasticity in the cerebellum under climbing fiber control. Neuron 44, 691-700. http://dx. doi.org/10.1016/j.neuron.2004.10.031.

Coutelier, M., Burglen, L., Mundwiller, E., Abada-Bendib, M., Rodriguez, D., ChantotBastaraud, S., Rougeot, C., Cournelle, M.-A., Milh, M., Toutain, A., Bacq, D., Meyer, V., Afenjar, A., Deleuze, J.-F., Brice, A., Héron, D., Stevanin, G., Durr, A., 2015. GRID2 mutations span from congenital to mild adult-onset cerebellar ataxia. Neurology http://dx.doi.org/10.1212/WNL.0000000000001524.

Daniel, H., Rancillac, A., Crepel, F., 2004. Mechanisms underlying cannabinoid inhibition of presynaptic $\mathrm{Ca}^{2+}$ influx at parallel fibre synapses of the rat cerebellum. J. Physiol. 557, 159-174. http://dx.doi.org/10.1113/jphysiol.2004.063263.

David, G., Abbas, N., Stevanin, G., Dürr, A, Yvert, G., Cancel, G., Weber, C., Imbert, G, Saudou, F., Antoniou, E., Drabkin, H., Gemmill, R., Giunti, P., Benomar, A., Wood, N., Ruberg, M., Agid, Y., Mandel, J.L., Brice, A., 1997. Cloning of the SCA7 gene reveals a highly unstable CAG repeat expansion. Nat. Genet. 17, 65-70. http://dx.doi.org/10. 1038/ng0997-65.

Davie, J.T., Clark, B.A., Häusser, M., 2008. The origin of the complex spike in cerebellar Purkinje cells. J. Neurosci. 28, 7599-7609. http://dx.doi.org/10.1523/JNEUROSCI. 0559-08.2008.

De Zeeuw, C.I., Hansel, C., Bian, F., Koekkoek, S.K., van Alphen, A.M., Linden, D.J., Oberdick, J., 1998. Expression of a protein kinase C inhibitor in Purkinje cells blocks cerebellar LTD and adaptation of the vestibulo-ocular reflex. Neuron 20, 495-508.

Delplanque, J., Devos, D., Huin, V., Genet, A., Sand, O., Moreau, C., Goizet, C., Charles, P., Anheim, M., Monin, M.L., Buée, L., Destée, A., Grolez, G., Delmaire, C., Dujardin, K., Dellacherie, D., Brice, A., Stevanin, G., Strubi-Vuillaume, I., Dürr, A., Sablonnière, B., 2014. TMEM240 mutations cause spinocerebellar ataxia 21 with mental retardation and severe cognitive impairment. Brain 137, 2657-2663. http://dx.doi.org/10.1093/ brain/awu202.

Devos, D., Schraen-Maschke, S., Vuillaume, I., Dujardin, K., Nazé, P., Willoteaux, C., Destée, A., Sablonnière, B., 2001. Clinical features and genetic analysis of a new form of spinocerebellar ataxia. Neurology 56, 234-238.

Di Gregorio, E., Borroni, B., Giorgio, E., Lacerenza, D., Ferrero, M., Lo Buono, N., Ragusa, N., Mancini, C., Gaussen, M., Calcia, A., Mitro, N., Hoxha, E., Mura, I., Coviello, D.A., Moon, Y.-A., Tesson, C., Vaula, G., Couarch, P., Orsi, L., Duregon, E., Papotti, M.G., Deleuze, J.-F., Imbert, J., Costanzi, C., Padovani, A., Giunti, P., Maillet-Vioud, M., Durr, A., Brice, A., Tempia, F., Funaro, A., Boccone, L., Caruso, D., Stevanin, G., Brusco, A., 2014. ELOVL5 mutations cause spinocerebellar ataxia 38. Am. J. Hum. Genet. 95, 209-217. http:// dx.doi.org/10.1016/j.ajhg.2014.07.001

Duarri, A., Jezierska, J., Fokkens, M., Meijer, M., Schelhaas, H.J., den Dunnen, W.F.A., van Dijk, F., Verschuuren-Bemelmans, C., Hageman, G., van de Vlies, P., Küsters, B., van de Warrenburg, B.P., Kremer, B., Wijmenga, C., Sinke, R.J., Swertz, M.A., Kampinga, H.H., Boddeke, E., Verbeek, D.S., 2012. Mutations in potassium channel kcnd3 cause spinocerebellar ataxia type 19. Ann. Neurol. 72, 870-880. http://dx.doi.org/10.1002/ ana. 23700 .

Dulneva, A., Lee, S., Oliver, P.L., Di Gleria, K., Kessler, B.M., Davies, K.E., Becker, E.B.E., 2015. The mutant moonwalker TRPC3 channel links calcium signaling to lipid metabolism in the developing cerebellum. Hum. Mol. Genet. http://dx.doi.org/10.1093/hmg/ ddv150.

Duvick, L., Barnes, J., Ebner, B., Agrawal, S., Andresen, M., Lim, J., Giesler, G.J., Zoghbi, H.Y., Orr, H.T., 2010. SCA1-like disease in mice expressing wild-type ataxin-1 with a serine to aspartic acid replacement at residue 776. Neuron 67, 929-935. http://dx.doi.org/ 10.1016/j.neuron.2010.08.022.

Ebner, B.A., Ingram, M.A., Barnes, J.A., Duvick, L.A., Frisch, J.L., Clark, H.B., Zoghbi, H.Y., Ebner, T.J., Orr, H.T., 2013. Purkinje cell ataxin-1 modulates climbing fiber synaptic input in developing and adult mouse cerebellum. J. Neurosci. 33, 5806-5820. http://dx.doi.org/10.1523/JNEUROSCI.6311-11.2013.

Eccles, J.C., Ito, M., Szentágothai, J., 1967. The Cerebellum as a Neuronal Machine. Springer, Berlin Heidelberg, Berlin, Heidelberg http://dx.doi.org/10.1007/9783-662-13147-3.

Eccles, J.C., Llinás, R., Sasaki, K., 1966. The excitatory synaptic action of climbing fibres on the Purkinje cells of the cerebellum. J. Physiol. 182, 268-296.

Finch, E.A., Augustine, G.J., 1998. Local calcium signalling by inositol-1,4,5-trisphosphate in Purkinje cell dendrites. Nature 396, 753-756. http://dx.doi.org/10. $1038 / 25541$

Flanigan, K., Gardner, K., Alderson, K., Galster, B., Otterud, B., Leppert, M.F., Kaplan, C., Ptácek, L.J., 1996. Autosomal dominant spinocerebellar ataxia with sensory axonal neuropathy (SCA4): clinical description and genetic localization to chromosome 16q22.1. Am. J. Hum. Genet. 59, 392-399.

Fogel, B.L., Hanson, S.M., Becker, E.B.E., 2015. Do mutations in the murine ataxia gene TRPC3 cause cerebellar ataxia in humans? Mov. Disord. 30, 284-286. http://dx.doi. org/10.1002/mds.26096.

Furrer, S.A., Mohanachandran, M.S., Waldherr, S.M., Chang, C., Damian, V.A., Sopher, B.L., Garden, G.A., La Spada, A.R., 2011. Spinocerebellar ataxia type 7 cerebellar disease requires the coordinated action of mutant ataxin-7 in neurons and glia, and displays non-cell-autonomous bergmann glia degeneration. J. Neurosci. 31, 16269-16278. http://dx.doi.org/10.1523/JNEUROSCI.4000-11.2011. 
Furrer, S.A., Waldherr, S.M., Mohanachandran, M.S., Baughn, T.D., Nguyen, K.-T., Sopher B.L., Damian, V.A., Garden, G.A., La Spada, A.R., 2013. Reduction of mutant ataxin-7 expression restores motor function and prevents cerebellar synaptic reorganization in a conditional mouse model of SCA7. Hum. Mol. Genet. 22, 890-903. http://dx.doi.org/ $10.1093 / \mathrm{hmg} / \mathrm{dds} 495$.

Gao, Y., Perkins, E.M., Clarkson, Y.L., Tobia, S., Lyndon, A.R., Jackson, M., Rothstein, J.D., 2011. $\beta$-III spectrin is critical for development of purkinje cell dendritic tree and spine morphogenesis. J. Neurosci. 31, 16581-16590. http://dx.doi.org/10.1523/ JNEUROSCI.3332-11.2011.

Han, V.Z., Grant, K., Bell, C.C., 2000. Reversible associative depression and nonassociative potentiation at a parallel fiber synapse. Neuron 27, 611-622.

Hansel, C., 2005. When the B-team runs plasticity: GluR2 receptor trafficking in cerebellar long-term potentiation. Proc. Natl. Acad. Sci. U. S. A. 102, 18245-18246. http://dx.doi. org/10.1073/pnas.0509686102.

Hansel, C., Linden, D.J., 2000. Long-term depression of the cerebellar climbing fiberPurkinje neuron synapse. Neuron 26, 473-482.

Hansel, C., de Jeu, M., Belmeguenai, A., Houtman, S.H., Buitendijk, G.H.S., Andreev, D., De Zeeuw, C.I., Elgersma, Y., 2006. AlphaCaMKII is essential for cerebellar LTD and motor learning. Neuron 51, 835-843. http://dx.doi.org/10.1016/j.neuron.2006.08. 013.

Hansel, C., Linden, D.J., D'Angelo, E., 2001. Beyond parallel fiber LTD: the diversity of synaptic and non-synaptic plasticity in the cerebellum. Nat. Neurosci. 4, 467-475.

Hartmann, J., Dragicevic, E., Adelsberger, H., Henning, H.A., Sumser, M., Abramowitz, J., Blum, R., Dietrich, A., Freichel, M., Flockerzi, V., Birnbaumer, L., Konnerth, A., 2008. TRPC3 channels are required for synaptic transmission and motor coordination. Neuron 59, 392-398. http://dx.doi.org/10.1016/j.neuron.2008.06.009.

He, Q., Titley, H., Grasselli, G., Piochon, C., Hansel, C., 2013. Ethanol affects NMDA receptor signaling at climbing fiber-Purkinje cell synapses in mice and impairs cerebellar LTD. J. Neurophysiol. 109, 1333-1342. http://dx.doi.org/10.1152/jn. 00350.2012

Hekman, K.E., Yu, G.-Y., Brown, C.D., Zhu, H., Du, X., Gervin, K., Undlien, D.E., Peterson, A., Stevanin, G., Clark, H.B., Pulst, S.M., Bird, T.D., White, K.P., Gomez, C.M., 2012. A conserved eEF2 coding variant in SCA26 leads to loss of translational fidelity and increased susceptibility to proteostatic insult. Hum. Mol. Genet. 21, 5472-5483. http://dx.doi.org/10.1093/hmg/dds392.

Higgins, J.J., Pho, L.T., Ide, S.E., Nee, L.E., Polymeropoulos, M.H., 1997. Evidence for a new spinocerebellar ataxia locus. Mov. Disord. 12, 412-417. http://dx.doi.org/10.1002/ mds.870120322.

Hirai, H., Pang, Z., Bao, D., Miyazaki, T., Li, L., Miura, E., Parris, J., Rong, Y., Watanabe, M., Yuzaki, M., Morgan, J.I., 2005. Cbln1 is essential for synaptic integrity and plasticity in the cerebellum. Nat. Neurosci. 8, 1534-1541. http://dx.doi.org/10.1038/nn1576.

Hirano, T., 2013. Long-term depression and other synaptic plasticity in the cerebellum. Proc. Jpn. Acad. Ser. B 89, 183-195.

Hollmann, M., Hartley, M., Heinemann, S., 1991. $\mathrm{Ca}^{2+}$ permeability of KA-AMPA-gated glutamate receptor channels depends on subunit composition. Science 252 (80-.), 851-853. http://dx.doi.org/10.1126/science.1709304.

Holmes, S.E., O'Hearn, E.E., McInnis, M.G., Gorelick-Feldman, D.A., Kleiderlein, J.J., Callahan, C., Kwak, N.G., Ingersoll-Ashworth, R.G., Sherr, M., Sumner, A.J., Sharp, A.H., Ananth, U., Seltzer, W.K., Boss, M.A., Vieria-Saecker, A.M., Epplen, J.T., Riess, O., Ross, C.A., Margolis, R.L., 1999. Expansion of a novel CAG trinucleotide repeat in the $5^{\prime}$ region of PPP2R2B is associated with SCA12. Nat. Genet. 23, 391-392. http://dx.doi.org/10. $1038 / 70493$.

Houlden, H., Johnson, J., Gardner-Thorpe, C., Lashley, T., Hernandez, D., Worth, P., Singleton, A.B., Hilton, D.A., Holton, J., Revesz, T., Davis, M.B., Giunti, P., Giunti, P., Wood, N.W., 2007. Mutations in TTBK2, encoding a kinase implicated in tau phosphorylation, segregate with spinocerebellar ataxia type 11. Nat. Genet. 39, 1434-1436. http://dx.doi.org/10.1038/ng.2007.43.

Huang, L., Chardon, J.W., Carter, M.T., Friend, K.L., Dudding, T.E., Schwartzentruber, J., Zou, R., Schofield, P.W., Douglas, S., Bulman, D.E., Boycott, K.M., 2012. Missense mutations in ITPR1 cause autosomal dominant congenital nonprogressive spinocerebellar ataxia. Orphanet J. Rare Dis. 7, 67. http://dx.doi.org/10.1186/1750-1172-7-67.

Huang, Y., Man, H.-Y., Sekine-Aizawa, Y., Han, Y., Juluri, K., Luo, H., Cheah, J., Lowenstein, C., Huganir, R.L., Snyder, S.H., 2005. S-nitrosylation of N-ethylmaleimide sensitive factor mediates surface expression of AMPA receptors. Neuron 46, 533-540. http://dx. doi.org/10.1016/j.neuron.2005.03.028.

Ichikawa, R., Miyazaki, T., Kano, M., Hashikawa, T., Tatsumi, H., Sakimura, K., Mishina, M., Inoue, Y., Watanabe, M., 2002. Distal extension of climbing fiber territory and multiple innervation caused by aberrant wiring to adjacent spiny branchlets in cerebellar Purkinje cells lacking glutamate receptor delta 2. J. Neurosci. 22, 8487-8503.

Ikeda, Y., Dick, K.A., Weatherspoon, M.R., Gincel, D., Armbrust, K.R., Dalton, J.C., Stevanin, G., Dürr, A., Zühlke, C., Bürk, K., Clark, H.B., Brice, A., Rothstein, J.D., Schut, L.J., Day, J.W., Ranum, L.P.W., 2006. Spectrin mutations cause spinocerebellar ataxia type 5. Nat. Genet. 38, 184-190. http://dx.doi.org/10.1038/ng1728.

Imbert, G., Saudou, F., Yvert, G., Devys, D., Trottier, Y., Garnier, J.M., Weber, C., Mandel, J.L., Cancel, G., Abbas, N., Dürr, A., Didierjean, O., Stevanin, G., Agid, Y., Brice, A., 1996. Cloning of the gene for spinocerebellar ataxia 2 reveals a locus with high sensitivity to expanded CAG/glutamine repeats. Nat. Genet. 14, 285-291. http://dx.doi.org/10. 1038/ng1196-285

Ito, M., 1982. Cerebellar control of the vestibulo-ocular reflex-around the flocculus hypothesis. Annu. Rev. Neurosci. 5, 275-296. http://dx.doi.org/10.1146/annurev.ne.05. 030182.001423.

Ito, M., 2006. Cerebellar circuitry as a neuronal machine. Prog. Neurobiol. 78, 272-303. http://dx.doi.org/10.1016/j.pneurobio.2006.02.006.

Iwaki, A., Kawano, Y., Miura, S., Shibata, H., Matsuse, D., Li, W., Furuya, H., Ohyagi, Y. Taniwaki, T., Kira, J., Fukumaki, Y., 2008. Heterozygous deletion of ITPR1, but not
SUMF1, in spinocerebellar ataxia type 16. J. Med. Genet. 45, 32-35. http://dx.doi. org/10.1136/jmg.2007.053942.

Jacoby, S., Sims, R.E., Hartell, N.A., 2001. Nitric oxide is required for the induction and heterosynaptic spread of long-term potentiation in rat cerebellar slices. J. Physiol. 535, 825-839.

Johnson, J.O., Stevanin, G., van de Leemput, J., Hernandez, D.G., Arepalli, S., Forlani, S. Zonozi, R., Gibbs, J.R., Brice, A., Durr, A., Singleton, A.B., 2015. A 7.5-Mb duplication at chromosome 11q21-11q22.3 is associated with a novel spastic ataxia syndrome. Mov. Disord. 30, 262-266. http://dx.doi.org/10.1002/mds.26059.

Kakegawa, W., Yuzaki, M., 2005. A mechanism underlying AMPA receptor trafficking during cerebellar long-term potentiation. Proc. Natl. Acad. Sci. U. S. A. 102, 17846-17851. http://dx.doi.org/10.1073/pnas.0508910102.

Kakegawa, W., Mitakidis, N., Miura, E., Abe, M., Matsuda, K., Takeo, Y.H., Kohda, K., Motohashi, J., Takahashi, A., Nagao, S., Muramatsu, S., Watanabe, M., Sakimura, K. Aricescu, A.R., Yuzaki, M., 2015. Anterograde C1ql1 signaling is required in order to determine and maintain a single-winner climbing fiber in the mouse cerebellum. Neuron 85, 316-329. http://dx.doi.org/10.1016/j.neuron.2014.12.020.

Kamouchi, M., Philipp, S., Flockerzi, V., Wissenbach, U., Mamin, A., Raeymaekers, L. Eggermont, J., Droogmans, G., Nilius, B., 1999. Properties of heterologously expressed hTRP3 channels in bovine pulmonary artery endothelial cells. J. Physiol. 518 (Pt 2) 345-358.

Kasumu, A., Bezprozvanny, I., 2012. Deranged calcium signaling in Purkinje cells and pathogenesis in spinocerebellar ataxia 2 (SCA2) and other ataxias. Cerebellum 11, 630-639. http://dx.doi.org/10.1007/s12311-010-0182-9.

Kawaguchi, Y., Okamoto, T., Taniwaki, M., Aizawa, M., Inoue, M., Katayama, S., Kawakami, H., Nakamura, S., Nishimura, M., Akiguchi, I., 1994. CAG expansions in a novel gene for Machado-Joseph disease at chromosome 14q32.1. Nat. Genet. 8, 221-228. http://dx doi.org/10.1038/ng1194-221.

Kim, S.J., 2013. TRPC3 channel underlies cerebellar long-term depression. Cerebellum 12 334-337. http://dx.doi.org/10.1007/s12311-013-0455-1.

Kita, Y., Tanaka, K., Murakami, F., 2015. Specific labeling of climbing fibers shows early synaptic interactions with immature Purkinje cells in the prenatal cerebellum. Dev. Neurobiol. http://dx.doi.org/10.1002/dneu.22259 (n/a-n/a.).

Knight, M.A., Gardner, R.J.M., Bahlo, M., Matsuura, T., Dixon, J.A., Forrest, S.M., Storey, E. 2004. Dominantly inherited ataxia and dysphonia with dentate calcification: spinocerebellar ataxia type 20. Brain 127, 1172-1181. http://dx.doi.org/10.1093/ brain/awh139.

Kobayashi, H., Abe, K., Matsuura, T., Ikeda, Y., Hitomi, T., Akechi, Y., Habu, T., Liu, W., Okuda H., Koizumi, A., 2011. Expansion of intronic GGCCTG hexanucleotide repeat in NOP56 causes SCA36, a type of spinocerebellar ataxia accompanied by motor neuron involvement. Am. J. Hum. Genet. 89, 121-130. http://dx.doi.org/10.1016/j.ajhg.2011.05.015.

Koide, R., Ikeuchi, T., Onodera, O., Tanaka, H., Igarashi, S., Endo, K., Takahashi, H., Kondo, R. Ishikawa, A., Hayashi, T., 1994. Unstable expansion of CAG repeat in hereditary dentatorubral-pallidoluysian atrophy (DRPLA). Nat. Genet. 6, 9-13. http://dx.doi. org/10.1038/ng0194-9.

Konnerth, A., Llano, I., Armstrong, C.M., 1990. Synaptic currents in cerebellar purkinje cells. Proc. Natl. Acad. Sci. U. S. A. 87, 2662-2665.

Koob, M.D., Moseley, M.L., Schut, L.J., Benzow, K.A., Bird, T.D., Day, J.W., Ranum, L.P., 1999 An untranslated CTG expansion causes a novel form of spinocerebellar ataxia (SCA8) Nat. Genet. 21, 379-384. http://dx.doi.org/10.1038/7710.

Koppen, M., Langer, T., 2007. Protein degradation within mitochondria: versatile activities of AAA proteases and other peptidases. Crit. Rev. Biochem. Mol. Biol. 42, 221-242. http://dx.doi.org/10.1080/10409230701380452.

Kreitzer, A.C., Regehr, W.G., 2001. Retrograde inhibition of presynaptic calcium influx by endogenous cannabinoids at excitatory synapses onto Purkinje cells. Neuron 29 717-727.

Le, T.D., Shirai, Y., Okamoto, T., Tatsukawa, T., Nagao, S., Shimizu, T. Ito, M., 2010. Lipid signaling in cytosolic phospholipase A2alpha-cyclooxygenase-2 cascade mediates cerebellar long-term depression and motor learning. Proc. Natl. Acad. Sci. U. S. A. 107 3198-3203. http://dx.doi.org/10.1073/pnas.0915020107.

Lee, Y.-C., Durr, A., Majczenko, K., Huang, Y.-H., Liu, Y.-C., Lien, C.-C., Tsai, P.-C., Ichikawa, Y., Goto, J., Monin, M.-L., Li, J.Z., Chung, M.-Y., Mundwiller, E., Shakkottai, V., Liu, T.T., Tesson, C., Lu, Y.-C., Brice, A., Tsuji, S., Burmeister, M., Stevanin, G., Soong, B.-W., 2012. Mutations in KCND3 cause spinocerebellar ataxia type 22. Ann. Neurol. 72 859-869. http://dx.doi.org/10.1002/ana.23701.

Leitges, M., Kovac, J., Plomann, M., Linden, D.J., 2004. A unique PDZ ligand in PKCalpha confers induction of cerebellar long-term synaptic depression. Neuron 44, 585-594 http://dx.doi.org/10.1016/j.neuron.2004.10.024

Levenes, C., Daniel, H., Crépel, F., 1998. Long-term depression of synaptic transmission in the cerebellum: cellular and molecular mechanisms revisited. Prog. Neurobiol. 55 79-91.

Lev-Ram, V., Jiang, T., Wood, J., Lawrence, D.S., Tsien, R.Y., 1997. Synergies and coincidence requirements between NO, cGMP, and $\mathrm{Ca} 2+$ in the induction of cerebellar long-term depression. Neuron 18, 1025-1038.

Lev-Ram, V., Makings, L.R., Keitz, P.F., Kao, J.P., Tsien, R.Y., 1995. Long-term depression in cerebellar Purkinje neurons results from coincidence of nitric oxide and depolarization-induced $\mathrm{Ca}^{2+}$ transients. Neuron 15, 407-415.

Lev-Ram, V., Mehta, S.B., Kleinfeld, D., Tsien, R.Y., 2003. Reversing cerebellar long-term depression. Proc. Natl. Acad. Sci. U. S. A. 100, 15989-15993. http://dx.doi.org/10.1073/ pnas.2636935100.

Lev-Ram, V., Wong, S.T., Storm, D.R., Tsien, R.Y., 2002. A new form of cerebellar long-term potentiation is postsynaptic and depends on nitric oxide but not cAMP. Proc. Natl. Acad. Sci. U. S. A. 99, 8389-8393. http://dx.doi.org/10.1073/pnas.122206399.

Linden, D.J., 2001. The expression of cerebellar LTD in culture is not associated with changes in AMPA-receptor kinetics, agonist affinity, or unitary conductance. Proc. Natl. Acad. Sci. 98, 14066-14071. http://dx.doi.org/10.1073/pnas.241384598. 
Linden, D.J., 2003. Neuroscience. From molecules to memory in the cerebellum. Science 301, 1682-1685. http://dx.doi.org/10.1126/science.1090462.

Linden, D.J., Ahn, S., 1999. Activation of presynaptic cAMP-dependent protein kinase is required for induction of cerebellar long-term potentiation. J. Neurosci. 19, 10221-10227.

Linden, D.J., Connor, J.A., 1991. Participation of postsynaptic PKC in cerebellar long-term depression in culture. Science 254, 1656-1659.

Linden, D.J., Connor, J.A., 1995. Long-term synaptic depression. Annu. Rev. Neurosci. 18, 319-357. http://dx.doi.org/10.1146/annurev.ne.18.030195.001535.

Llano, I., Marty, A., Armstrong, C.M., Konnerth, A., 1991. Synaptic- and agonist-induced excitatory currents of Purkinje cells in rat cerebellar slices. J. Physiol. 434, 183-213.

Maltecca, F., Aghaie, A., Schroeder, D.G., Cassina, L., Taylor, B.A., Phillips, S.J., Malaguti, M., Previtali, S., Guénet, J.-L., Quattrini, A., Cox, G.A., Casari, G., 2008. The mitochondrial protease AFG3L2 is essential for axonal development. J. Neurosci. 28, 2827-2836. http://dx.doi.org/10.1523/JNEUROSCI.4677-07.2008.

Maltecca, F., Baseggio, E., Consolato, F., Mazza, D., Podini, P., Young, S.M., Drago, I., Bahr, B.A., Puliti, A., Codazzi, F., Quattrini, A., Casari, G., 2015. Purkinje neuron $\mathrm{Ca}^{2+}$ influx reduction rescues ataxia in SCA28 model. J. Clin. Invest. 125, 263-274. http://dx.doi. org $10.1172 / \mathrm{JCI} 74770$.

Mariotti, C., Brusco, A., Di Bella, D., Cagnoli, C., Seri, M., Gellera, C., Di Donato, S., Taroni, F. 2008. Spinocerebellar ataxia type 28: a novel autosomal dominant cerebellar ataxia characterized by slow progression and ophthalmoparesis. Cerebellum 7, 184-188. http://dx.doi.org/10.1007/s12311-008-0053-9.

Mathy, A., Ho, S.S.N., Davie, J.T., Duguid, I.C., Clark, B.A., Häusser, M., 2009. Encoding of oscillations by axonal bursts in inferior olive neurons. Neuron 62, 388-399. http://dx. doi.org/10.1016/j.neuron.2009.03.023.

Matilla-Dueñas, A., Ashizawa, T., Brice, A., Magri, S., McFarland, K.N., Pandolfo, M., Pulst, S.M., Riess, O., Rubinsztein, D.C., Schmidt, J., Schmidt, T., Scoles, D.R., Stevanin, G. Taroni, F., Underwood, B.R., Sánchez, I., 2013. Consensus paper: pathological mechanisms underlying neurodegeneration in spinocerebellar ataxias. Cerebellum http:// dx.doi.org/10.1007/s12311-013-0539-y.

Matilla-Dueñas, A., Ashizawa, T., Brice, A., Magri, S., McFarland, K.N., Pandolfo, M., Pulst, S.M., Riess, O., Rubinsztein, D.C., Schmidt, J., Schmidt, T., Scoles, D.R., Stevanin, G. Taroni, F., Underwood, B.R., Sánchez, I., 2014. Consensus paper: pathological mechanisms underlying neurodegeneration in spinocerebellar ataxias. Cerebellum 13 , 269-302. http://dx.doi.org/10.1007/s12311-013-0539-y.

Matsuura, T., Yamagata, T., Burgess, D.L., Rasmussen, A., Grewal, R.P., Watase, K., Khajavi, M., McCall, A.E., Davis, C.F., Zu, L., Achari, M., Pulst, S.M., Alonso, E., Noebels, J.L. Nelson, D.L., Zoghbi, H.Y., Ashizawa, T., 2000. Large expansion of the ATTCT pentanucleotide repeat in spinocerebellar ataxia type 10. Nat. Genet. 26, 191-194. http://dx.doi.org/10.1038/79911.

Mayer, M.L., Westbrook, G.L., 1987. Permeation and block of N-methyl-D-aspartic acid receptor channels by divalent cations in mouse cultured central neurons. J. Physiol. 394, 501-527.

Medina, J.F., Nores, W.L., Ohyama, T., Mauk, M.D., 2000. Mechanisms of cerebellar learning suggested by eyelid conditioning. Curr. Opin. Neurobiol. 10, 717-724.

Miyakawa, H., Lev-Ram, V., Lasser-Ross, N., Ross, W.N., 1992. Calcium transients evoked by climbing fiber and parallel fiber synaptic inputs in guinea pig cerebellar Purkinje neurons. J. Neurophysiol. 68, 1178-1189.

Miyata, T. Ono, Y, Okamoto, M., Masaoka, M., Sakakibara, A, Kawaguchi, A., Hashimoto, M., Ogawa, M., 2010. Migration, early axonogenesis, and reelin-dependent layerforming behavior of early/posterior-born Purkinje cells in the developing mouse lateral cerebellum. Neural Dev. 5, 23. http://dx.doi.org/10.1186/1749-8104-5-23.

Miyazaki, T., Hashimoto, K., Shin, H.-S., Kano, M., Watanabe, M., 2004. P/Q-type Ca ${ }^{2+}$ channel alpha1A regulates synaptic competition on developing cerebellar Purkinje cells. J. Neurosci. 24, 1734-1743. http://dx.doi.org/10.1523/ JNEUROSCI.4208-03.2004.

Miyazaki, T., Yamasaki, M., Takeuchi, T., Sakimura, K., Mishina, M., Watanabe, M., 2010. Ablation of glutamate receptor GluRס2 in adult Purkinje cells causes multiple innervation of climbing fibers by inducing aberrant invasion to parallel fiber innervation territory. J. Neurosci. 30, 15196-15209. http://dx.doi.org/10.1523/JNEUROSCI.093410.2010.

Murthy, S.E., Shogan, T., Page, J.C., Kasperek, E.M., Popescu, G.K., 2012. Probing the activation sequence of NMDA receptors with lurcher mutations. J. Gen. Physiol. 140 267-277. http://dx.doi.org/10.1085/jgp.201210786.

Najafi, F., Medina, J.F., 2013. Beyond “all-or-nothing” climbing fibers: graded representation of teaching signals in Purkinje cells. Front. Neural Circ. 7, 115. http://dx.doi.org/ 10.3389/fncir.2013.00115.

Nakamura, K., Jeong, S.Y., Uchihara, T., Anno, M., Nagashima, K., Nagashima, T., Ikeda, S. Tsuji, S., Kanazawa, I., 2001. SCA17, a novel autosomal dominant cerebellar ataxia caused by an expanded polyglutamine in TATA-binding protein. Hum. Mol. Genet. $10,1441-1448$.

Ohtsuki, G., Piochon, C., Hansel, C., 2009. Climbing fiber signaling and cerebellar gain control. Front. Cell. Neurosci. 3, 4. http://dx.doi.org/10.3389/neuro.03.004.2009.

Orr, H.T., Chung, M.Y., Banfi, S., Kwiatkowski, T.J., Servadio, A., Beaudet, A.L., McCall, A.E., Duvick, L.A., Ranum, L.P., Zoghbi, H.Y., 1993. Expansion of an unstable trinucleotide CAG repeat in spinocerebellar ataxia type 1 . Nat. Genet. 4, 221-226. http://dx.doi. org/10.1038/ng0793-221.

Perkel, D.J., Hestrin, S., Sah, P., Nicoll, R.A., 1990. Excitatory synaptic currents in Purkinje cells. Proc. Biol. Sci. 241, 116-121. http://dx.doi.org/10.1098/rspb.1990.0074.

Perkins, E.M., Clarkson, Y.L., Sabatier, N., Longhurst, D.M., Millward, C.P., Jack, J., Toraiwa, J., Watanabe, M., Rothstein, J.D., Lyndon, A.R., Wyllie, D.J.A., Dutia, M.B., Jackson, M., 2010. Loss of beta-III spectrin leads to Purkinje cell dysfunction recapitulating the behavior and neuropathology of spinocerebellar ataxia type 5 in humans. J. Neurosci. 30, 4857-4867. http://dx.doi.org/10.1523/JNEUROSCI. 6065-09.2010.
Piochon, C., Irinopoulou, T., Brusciano, D., Bailly, Y., Mariani, J., Levenes, C., 2007. NMDA receptor contribution to the climbing fiber response in the adult mouse Purkinje cell. J. Neurosci. 27, 10797-10809. http://dx.doi.org/10.1523/JNEUROSCI.2422-07. 2007.

Piochon, C., Levenes, C., Ohtsuki, G., Hansel, C., 2010. Purkinje cell NMDA receptors assume a key role in synaptic gain control in the mature cerebellum. J. Neurosci. 30, 15330-15335. http://dx.doi.org/10.1523/JNEUROSCI.4344-10.2010.

Pulst, S.M., Nechiporuk, A., Nechiporuk, T., Gispert, S., Chen, X.N., Lopes-Cendes, I., Pearlman, S., Starkman, S., Orozco-Diaz, G., Lunkes, A., DeJong, P., Rouleau, G.A., Auburger, G., Korenberg, J.R., Figueroa, C., Sahba, S., 1996. Moderate expansion of a normally biallelic trinucleotide repeat in spinocerebellar ataxia type 2 . Nat. Genet. 14, 269-276. http://dx.doi.org/10.1038/ng1196-269.

Qiu, D., Knöpfel, T., 2008. Presynaptically expressed long-term depression at cerebellar parallel fiber synapses. Pflugers Arch. - Eur. J. Physiol. 457, 865-875. http://dx.doi. org/10.1007/s00424-008-0555-9.

Raman, I.M., Bean, B.P., 1997. Resurgent sodium current and action potential formation in dissociated cerebellar Purkinje neurons. J. Neurosci. 17, 4517-4526.

Raman, I.M., Bean, B.P., 1999a. Ionic currents underlying spontaneous action potentials in isolated cerebellar Purkinje neurons. J. Neurosci. 19, 1663-1674.

Raman, I.M., Bean, B.P., 1999b. Properties of sodium currents and action potential firing in isolated cerebellar Purkinje neurons. Ann. N. Y. Acad. Sci. 868, 93-96.

Renzi, M., Farrant, M., Cull-Candy, S.G., 2007. Climbing-fibre activation of NMDA receptors in Purkinje cells of adult mice. J. Physiol. 585, 91-101. http://dx.doi.org/10.1113/ jphysiol.2007.141531

Riccio, A., Medhurst, A.D., Mattei, C., Kelsell, R.E., Calver, A.R., Randall, A.D., Benham, C.D., Pangalos, M.N., 2002. MRNA distribution analysis of human TRPC family in CNS and peripheral tissues. Brain Res. Mol. Brain Res. 109, 95-104.

Safo, P.K., Regehr, W.G., 2005. Endocannabinoids control the induction of cerebellar LTD. Neuron 48, 647-659. http://dx.doi.org/10.1016/j.neuron.2005.09.020.

Salin, P.A., Malenka, R.C., Nicoll, R.A., 1996. Cyclic AMP mediates a presynaptic form of LTP at cerebellar parallel fiber synapses. Neuron 16, 797-803.

Sanpei, K., Takano, H., Igarashi, S., Sato, T., Oyake, M., Sasaki, H., Wakisaka, A., Tashiro, K., Ishida, Y., Ikeuchi, T., Koide, R., Saito, M., Sato, A., Tanaka, T., Hanyu, S., Takiyama, Y., Nishizawa, M., Shimizu, N., Nomura, Y., Segawa, M., Iwabuchi, K., Eguchi, I., Tanaka, H., Takahashi, H., Tsuji, S., 1996. Identification of the spinocerebellar ataxia type 2 gene using a direct identification of repeat expansion and cloning technique, DIRECT. Nat. Genet. 14, 277-284. http://dx.doi.org/10.1038/ng1196-277.

Sato, N., Amino, T., Kobayashi, K., Asakawa, S., Ishiguro, T., Tsunemi, T., Takahashi, M., Matsuura, T., Flanigan, K.M., Iwasaki, S., Ishino, F., Saito, Y., Murayama, S., Yoshida, M., Hashizume, Y., Takahashi, Y., Tsuji, S., Shimizu, N., Toda, T., Ishikawa, K., Mizusawa, H., 2009. Spinocerebellar ataxia type 31 is associated with "inserted" penta-nucleotide repeats containing (TGGAA)n. Am. J. Hum. Genet. 85, 544-557. http://dx.doi.org/10.1016/j.ajhg.2009.09.019.

Schmolesky, M.T., De Zeeuw, C.I., Hansel, C., 2005. Climbing fiber synaptic plasticity and modifications in Purkinje cell excitability. Prog. Brain Res. 148, 81-94. http://dx.doi. org/10.1016/S0079-6123(04)48008-X.

Schmolesky, M.T., Weber, J.T., De Zeeuw, C.I., Hansel, C., 2002. The making of a complex spike: ionic composition and plasticity. Ann. N. Y. Acad. Sci. 978, 359-390.

Schonewille, M., Belmeguenai, A., Koekkoek, S.K., Houtman, S.H., Boele, H.J., van Beugen, B.J., Gao, Z., Badura, A., Ohtsuki, G., Amerika, W.E., Hosy, E., Hoebeek, F.E., Elgersma, Y., Hansel, C., De Zeeuw, C.I., 2010. Purkinje cell-specific knockout of the protein phosphatase PP2B impairs potentiation and cerebellar motor learning. Neuron 67, 618-628. http://dx.doi.org/10.1016/j.neuron.2010.07.009.

Serrano-Munuera, C., Corral-Juan, M., Stevanin, G., San Nicolás, H., Roig, C., Corral, J., Campos, B., de Jorge, L., Morcillo-Suárez, C., Navarro, A., Forlani, S., Durr, A., Kulisevsky, J., Brice, A., Sánchez, I., Volpini, V., Matilla-Dueñas, A., 2013. New subtype of spinocerebellar ataxia with altered vertical eye movements mapping to chromosome 1p32. JAMA Neurol. 70 , 764-771. http://dx.doi.org/10.1001/jamaneurol.2013.2311.

Shen, Y., Hansel, C., Linden, D.J., 2002. Glutamate release during LTD at cerebellar climbing fiber-Purkinje cell synapses. Nat. Neurosci. 5, 725-726. http://dx.doi.org/10.1038/ nn895.

Shin, J.H., Linden, D.J., 2005. An NMDA receptor/nitric oxide cascade is involved in cerebellar LTD but is not localized to the parallel fiber terminal. J. Neurophysiol. 94, 4281-4289. http://dx.doi.org/10.1152/jn.00661.2005.

Shuvaev, A.N., Horiuchi, H., Seki, T., Goenawan, H., Irie, T., Iizuka, A., Sakai, N., Hirai, H., 2011. Mutant PKC $\gamma$ in spinocerebellar ataxia type 14 disrupts synapse elimination and long-term depression in Purkinje cells in vivo. J. Neurosci. 31, 14324-14334. http://dx.doi.org/10.1523/JNEUROSCI.5530-10.2011.

Smeets, C.J.L.M., Verbeek, D.S., 2014. Cerebellar ataxia and functional genomics: identifying the routes to cerebellar neurodegeneration. Biochim. Biophys. Acta 1842, 2030-2038. http://dx.doi.org/10.1016/j.bbadis.2014.04.004.

Smeets, C.J.L.M., Jezierska, J., Watanabe, H., Duarri, A., Fokkens, M.R., Meijer, M., Zhou, Q., Yakovleva, T., Boddeke, E., den Dunnen, W., van Deursen, J., Bakalkin, G., Kampinga, H.H., van de Sluis, B., Verbeek, D.S., 2015. Elevated mutant dynorphin a causes Purkinje cell loss and motor dysfunction in spinocerebellar ataxia type 23. Brain 138, 2537-2552. http://dx.doi.org/10.1093/brain/awv195.

Stankewich, M.C., Gwynn, B., Ardito, T., Ji, L., Kim, J., Robledo, R.F., Lux, S.E., Peters, L.L., Morrow, J.S., 2010. Targeted deletion of betaIII spectrin impairs synaptogenesis and generates ataxic and seizure phenotypes. Proc. Natl. Acad. Sci. U. S. A. 107, 6022-6027. http://dx.doi.org/10.1073/pnas.1001522107.

Stevanin, G., Broussolle, E., Streichenberger, N., Kopp, N., Brice, A., Durr, A., 2005. Spinocerebellar ataxia with sensory neuropathy (SCA25). Cerebellum 4, 58-61. http://dx.doi.org/10.1080/14734220510007932.

Storey, E., Bahlo, M., Fahey, M., Sisson, O., Lueck, C.J., Gardner, R.J.M., 2009. A new dominantly inherited pure cerebellar ataxia, SCA 30. J. Neurol. Neurosurg. Psychiatry 80, 408-411. http://dx.doi.org/10.1136/jnnp.2008.159459. 
Storm, D.R., Hansel, C., Hacker, B., Parent, A., Linden, D.J., 1998. Impaired cerebellar longterm potentiation in type I adenylyl cyclase mutant mice. Neuron 20, 1199-1210.

Strata, P., Rossi, F., 1998. Plasticity of the olivocerebellar pathway. Trends Neurosci. 21, 407-413.

Su, L.-D., Shen, Y., 2009. Blockade of glutamate transporters facilitates cerebellar synaptic long-term depression. Neuroreport 20, 502-507. http://dx.doi.org/10.1097/WNR. 0b013e328328f397.

Swartz, B.E., Burmeister, M., Somers, J.T., Rottach, K.G., Bespalova, I.N., Leigh, R.J., 2002. A form of inherited cerebellar ataxia with saccadic intrusions, increased saccadic speed, sensory neuropathy, and myoclonus. Ann. N. Y. Acad. Sci. 956, 441-444.

Takahashi, K.A., Linden, D.J., 2000. Cannabinoid receptor modulation of synapses received by cerebellar Purkinje cells. J. Neurophysiol. 83, 1167-1180.

Takechi, H., Eilers, J., Konnerth, A., 1998. A new class of synaptic response involving calcium release in dendritic spines. Nature 396, 757-760. http://dx.doi.org/10.1038/ 25547.

Titley, H.K., Hansel, C., 2015. Asymmetries in cerebellar plasticity and motor learning. Cerebellum http://dx.doi.org/10.1007/s12311-014-0635-7.

Tsoi, H., Yu, A.C.S., Chen, Z.S., Ng, N.K.N., Chan, A.Y.Y., Yuen, L.Y.P., Abrigo, J.M., Tsang, S.Y., Tsui, S.K.W., Tong, T.M.F., Lo, I.F.M., Lam, S.T.S., Mok, V.C.T., Wong, L.K.S., Ngo, J.C.K., Lau, K.-F., Chan, T.-F., Chan, H.Y.E., 2014. A novel missense mutation in CCDC88C activates the JNK pathway and causes a dominant form of spinocerebellar ataxia. J. Med. Genet. 51, 590-595. http://dx.doi.org/10.1136/jmedgenet-2014-102333.

Tsutsumi, S., Yamazaki, M., Miyazaki, T., Watanabe, M., Sakimura, K., Kano, M., Kitamura, K., 2015. Structure-function relationships between aldolase C/zebrin II expression and complex spike synchrony in the cerebellum. J. Neurosci. 35, 843-852. http://dx. doi.org/10.1523/JNEUROSCI.2170-14.2015.

Uesaka, N., Uchigashima, M., Mikuni, T., Hirai, H., Watanabe, M., Kano, M., 2015. Retrograde signaling for climbing fiber synapse elimination. Cerebellum http://dx.doi. org/10.1007/s12311-014-0615-y.

Uesaka, N., Uchigashima, M., Mikuni, T., Nakazawa, T., Nakao, H., Hirai, H., Aiba, A., Watanabe, M., Kano, M., 2014. Retrograde semaphorin signaling regulates synapse elimination in the developing mouse brain. Science 344, 1020-1023. http://dx.doi. org/10.1126/science.1252514.

Valdmanis, P.N., Dupré, N., Lachance, M., Stochmanski, S.J., Belzil, V.V., Dion, P.A., Thiffault, I., Brais, B., Weston, L., Saint-Amant, L., Samuels, M.E., Rouleau, G.A., 2011. A mutation in the RNF170 gene causes autosomal dominant sensory ataxia. Brain 134, 602-607. http://dx.doi.org/10.1093/brain/awq329.

van Beugen, B.J., Nagaraja, R.Y., Hansel, C., 2006. Climbing fiber-evoked endocannabinoid signaling heterosynaptically suppresses presynaptic cerebellar long-term potentiation. J. Neurosci. 26, 8289-8294. http://dx.doi.org/10.1523/JNEUROSCI.0805-06.2006.

van Beugen, B.J., Qiao, X., Simmons, D.H., De Zeeuw, C.I., Hansel, C., 2014. Enhanced AMPA receptor function promotes cerebellar long-term depression rather than potentiation. Learn. Mem. 21, 662-667. http://dx.doi.org/10.1101/lm.035220.114.

van de Leemput, J., Chandran, J., Knight, M.A., Holtzclaw, L.A., Scholz, S., Cookson, M.R., Houlden, H., Gwinn-Hardy, K., Fung, H.-C., Lin, X., Hernandez, D., Simon-Sanchez, J., Wood, N.W., Giunti, P., Rafferty, I., Hardy, J., Storey, E., Gardner, R.J.M., Forrest, S.M., Fisher, E.M.C., Russell, J.T., Cai, H., Singleton, A.B., 2007. Deletion at ITPR1 underlies ataxia in mice and spinocerebellar ataxia 15 in humans. PLoS Genet. 3, e108. http:// dx.doi.org/10.1371/journal.pgen.0030108.

van Swieten, J.C., Brusse, E., de Graaf, B.M., Krieger, E., van de Graaf, R., de Koning, I., MaatKievit, A., Leegwater, P., Dooijes, D., Oostra, B.A., Heutink, P., 2003. A mutation in the fibroblast growth factor 14 gene is associated with autosomal dominant cerebellar ataxia [corrected]. Am. J. Hum. Genet. 72, 191-199.

Wadiche, J.I., Jahr, C.E., 2001. Multivesicular release at climbing fiber-Purkinje cell synapses. Neuron 32, 301-313.
Wang, D.-J., Su, L.-D., Wang, Y.-N., Yang, D., Sun, C.-L., Zhou, L., Wang, X.-X., Shen, Y., 2014 Long-term potentiation at cerebellar parallel fiber-Purkinje cell synapses requires presynaptic and postsynaptic signaling cascades. J. Neurosci. 34, 2355-2364. http:// dx.doi.org/10.1523/JNEUROSCI.4064-13.2014.

Wang, J.L., Yang, X., Xia, K., Hu, Z.M., Weng, L., Jin, X., Jiang, H., Zhang, P., Shen, L., Guo, J.F. Li, N., Li, Y.R., Lei, L.F., Zhou, J., Du, J., Zhou, Y.F., Pan, Q., Wang, J., Wang, J., Li, R.Q., Tang, B.S., 2010. TGM6 identified as a novel causative gene of spinocerebellar ataxias using exome sequencing. Brain 133, 3510-3518. http://dx.doi.org/10.1093/brain/awq323.

Wang, S.S., Denk, W., Häusser, M., 2000. Coincidence detection in single dendritic spines mediated by calcium release. Nat. Neurosci. 3, 1266-1273. http://dx.doi.org/10.1038/ 81792.

Wang, W., Nakadate, K., Masugi-Tokita, M., Shutoh, F., Aziz, W., Tarusawa, E., Lorincz, A. Molnár, E., Kesaf, S., Li, Y.-Q., Fukazawa, Y., Nagao, S., Shigemoto, R., 2013. Distinct cerebellar engrams in short-term and long-term motor learning. Proc. Natl. Acad. Sci. U. S. A. 1-6. http://dx.doi.org/10.1073/pnas.1315541111/-/DCSupplemental (www.pnas.org/cgi/doi/10.1073/pnas.1315541111).

Wang, Y.T., Linden, D.J., 2000. Expression of cerebellar long-term depression requires postsynaptic clathrin-mediated endocytosis. Neuron 25, 635-647.

Watanabe, M., Kano, M., 2011. Climbing fiber synapse elimination in cerebellar Purkinje cells. Eur. J. Neurosci. 34, 1697-1710. http://dx.doi.org/10.1111/j.1460-9568.2011. 07894.x.

Waters, M.F., Minassian, N.A., Stevanin, G., Figueroa, K.P., Bannister, J.P.A., Nolte, D., Mock, A.F., Evidente, V.G.H., Fee, D.B., Müller, U., Dürr, A., Brice, A., Papazian, D.M., Pulst, S.M. 2006. Mutations in voltage-gated potassium channel KCNC3 cause degenerative and developmental central nervous system phenotypes. Nat. Genet. 38, 447-451. http:// dx.doi.org/10.1038/ng1758.

Weber, J.T., De Zeeuw, C.I., Linden, D.J., Hansel, C., 2003. Long-term depression of climbing fiber-evoked calcium transients in Purkinje cell dendrites. Proc. Natl. Acad. Sci. U. S. A 100, 2878-2883. http://dx.doi.org/10.1073/pnas.0536420100.

Welsh, J.P., Llinás, R., 1997. Some organizing principles for the control of movement based on olivocerebellar physiology. Prog. Brain Res. 114, 449-461.

Wojda, U., Salinska, E., Kuznicki, J., 2008. Calcium ions in neuronal degeneration. IUBMB Life 60, 575-590. http://dx.doi.org/10.1002/iub.91 (in review).

Xia, J., Chung, H.J., Wihler, C., Huganir, R.L., Linden, D.J., 2000. Cerebellar long-term depression requires PKC-regulated interactions between GluR2/3 and PDZ domaincontaining proteins. Neuron 28, 499-510.

Yuan, H., Hansen, K.B., Zhang, J., Pierson, T.M., Markello, T.C., Fajardo, K.V.F., Holloman, C.M., Golas, G., Adams, D.R., Boerkoel, C.F., Gahl, W.A., Traynelis, S.F., 2014. Functional analysis of a de novo GRIN2A missense mutation associated with early-onset epileptic encephalopathy. Nat. Commun. 5, 3251. http://dx.doi.org/10.1038/ncomms4251.

Yuan, Q., Qiu, D.-L., Weber, J.T., Hansel, C., Knöpfel, T., 2007. Climbing fiber-triggered metabotropic slow potentials enhance dendritic calcium transients and simple spike firing in cerebellar Purkinje cells. Mol. Cell. Neurosci. 35, 596-603. http://dx.doi.org/10. 1016/j.mcn.2007.05.004.

Zhuchenko, O., Bailey, J., Bonnen, P., Ashizawa, T., Stockton, D.W., Amos, C., Dobyns, W.B., Subramony, S.H., Zoghbi, H.Y., Lee, C.C., 1997. Autosomal dominant cerebellar ataxia (SCA6) associated with small polyglutamine expansions in the alpha $1 \mathrm{~A}$-voltagedependent calcium channel. Nat. Genet. 15, 62-69. http://dx.doi.org/10.1038/ ng0197-62.

Zuo, J., De Jager, P.L., Takahashi, K.A., Jiang, W., Linden, D.J., Heintz, N., 1997. Neurodegeneration in Lurcher mice caused by mutation in delta2 glutamate receptor gene. Nature 388, 769-773. http://dx.doi.org/10.1038/42009. 